\title{
Faulting, Damage, and Intensity in the Canyondam Earthquake of May 23, 2013
}

By K. Chapman, M.B. Gold, John Boatwright, J. Sipe, V. Quitoriano, D. Dreger, and Jeanne Hardebeck

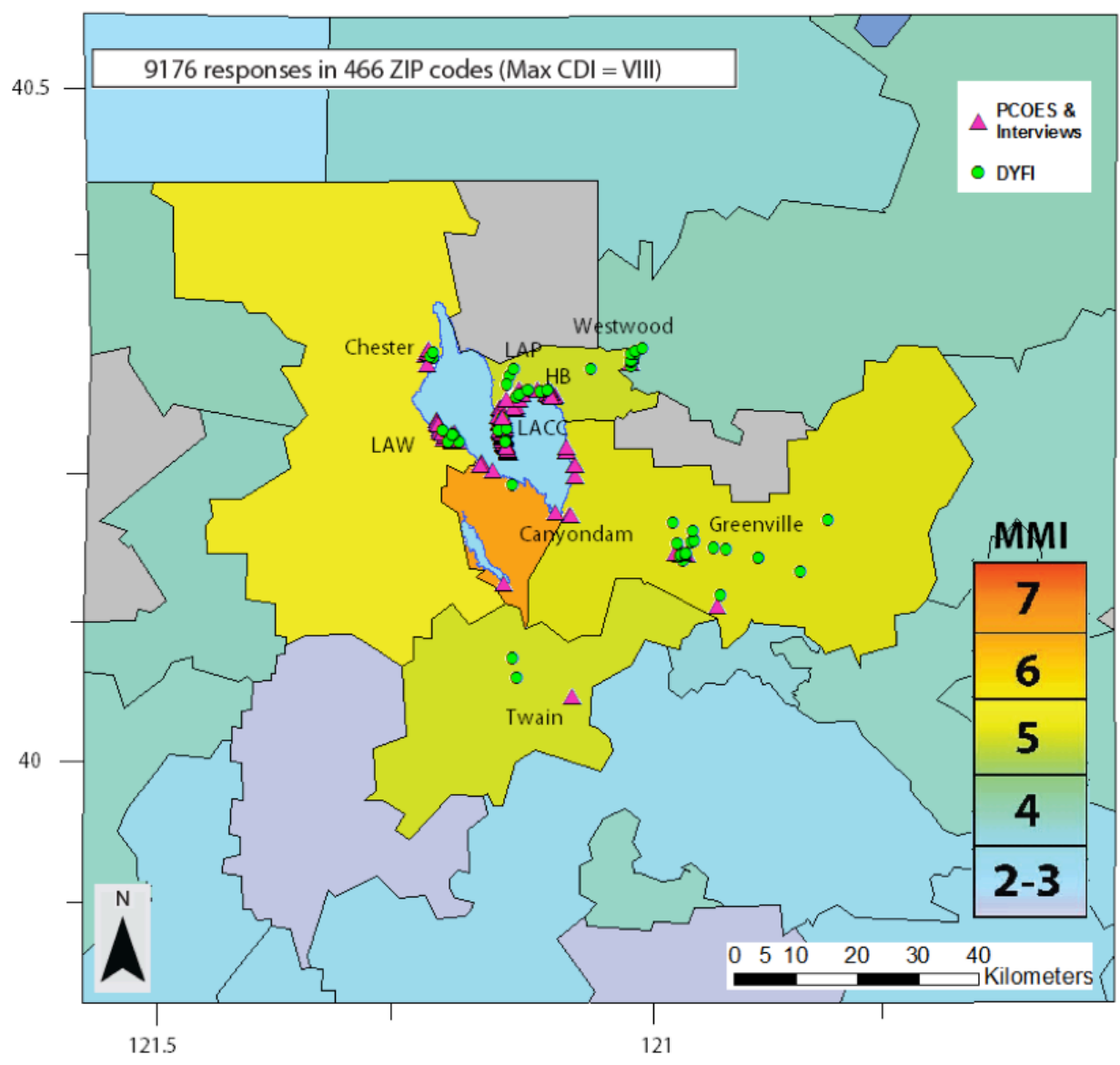

Open-File Report 2016-1145

U.S. Department of the Interior

U.S. Geological Survey 
Cover. "Did You Feel It" (DYFI) ZIP-Code map for the area around Lake Almanor, California. Locations for interviews, the Plumas County Office of Emergency Services reports, and the geocoded DYFI reports are superimposed on the map. MMI, Modified Mercalli Intensity. 


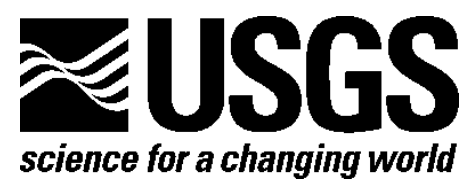

\section{Faulting, Damage, and Intensity in the Canyondam Earthquake of May 23, 2013}

By K. Chapman, M.B. Gold, John Boatwright, J. Sipe, V. Quitoriano, D. Dreger, and Jeanne Hardebeck

Open-File Report 2016-1145

U.S. Department of the Interior

U.S. Geological Survey 


\section{U.S. Department of the Interior \\ SALLY JEWELL, Secretary}

\section{U.S. Geological Survey \\ Suzette M. Kimball, Director}

U.S. Geological Survey, Reston, Virginia: 2016

For more information on the USGS—-the Federal source for science about the Earth,

its natural and living resources, natural hazards, and the environment-visit

http://www.usgs.gov/ or call 1-888-ASK-USGS (1-888-275-8747).

For an overview of USGS information products, including maps, imagery, and publications, visit http://store.usgs.gov/.

Any use of trade, firm, or product names is for descriptive purposes only and does not imply endorsement by the U.S. Government.

Although this information product, for the most part, is in the public domain, it also may contain copyrighted materials as noted in the text. Permission to reproduce copyrighted items must be secured from the copyright owner.

Suggested citation:

Chapman, K., Gold, M.B., Boatwright, J., Sipe, J., Quitoriano, V., Dreger, D., and Hardebeck, J., 2016, Faulting, damage, and intensity in the Canyondam earthquake of May 23, 2013: U.S. Geological Survey Open-File Report 2016-1145, 49 p., http://dx.doi.org/10.3133/ofr20161145.

ISSN: 2328-0328 (online) 


\section{Acknowledgments}

We are indebted to Keith Knudsen and Eleyne Phillips for reviewing this report and to Walter Mooney for facilitating our work on this project. Don Hoirup of the California Department of Water Resources suggested that the U.S. Geological Survey (USGS) look for surface faulting. Marjorie Greene and Maggie Ortiz of the Earthquake Engineering Research Institute encouraged us to post photographs of the damage on their Web site. Conversations with Jim Dewey and Dave Wald (USGS) helped us understand the damage effects. Jeffrey Hunt and Fred Turner of the California Seismic Safety Commission told us about Curt Haselton's assessment of damage to the Lake Almanor Fire Station for the Structural Engineering Association of California. Anna Sojourner of the California Department of Transportation gave us the locations of the rock fall and the small slide that were cleared by Caltrans the night of the earthquake. Jeffrey Morrish of NST Engineering, Inc., gave us the location of the crack near Lassen View Drive and described the damage to a house in Lake Almanor West that we had not visited. We would particularly like to thank the residents of Lake Almanor who provided us with their invaluable accounts of the earthquake and photographs of the damage. 


\section{Contents}

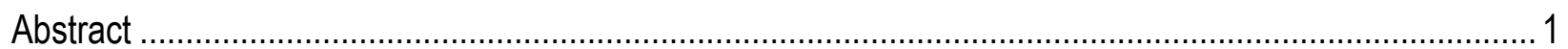

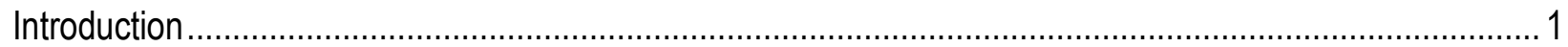

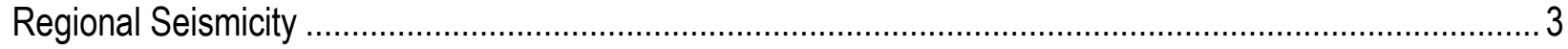

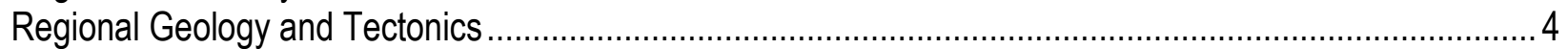

Earthquake Mechanism, Fault, and Rupture Extent ………..........................................................

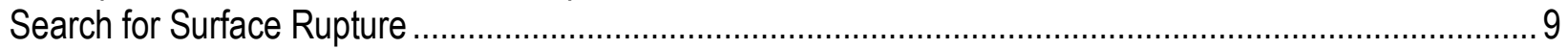

Postearthquake Damage Assessment.............................................................................................. 10

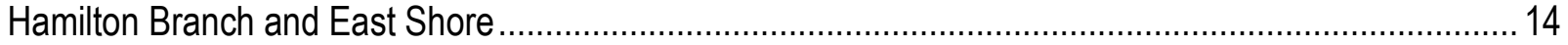

Lake Almanor Country Club and Lake Almanor Peninsula ................................................................ 14

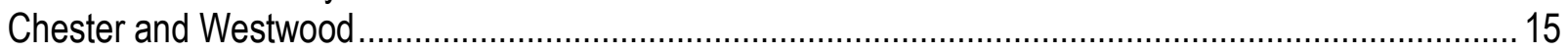

Lake Almanor West............................................................................................................... 15

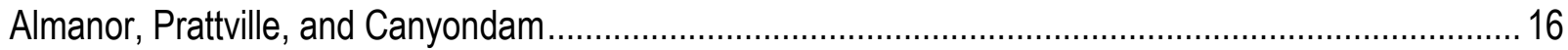

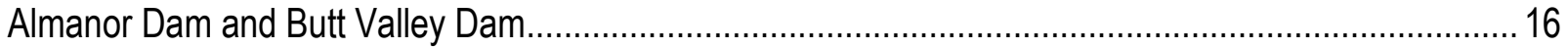

Greenville, Crescent Mills, and Twain ...................................................................................... 16

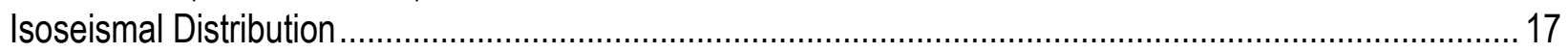

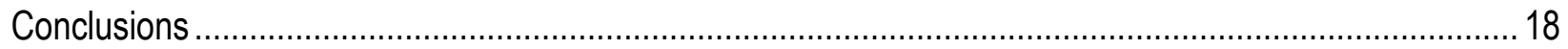

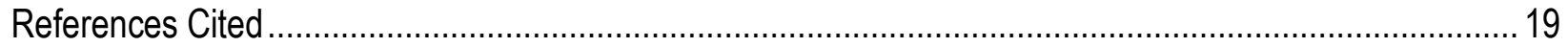

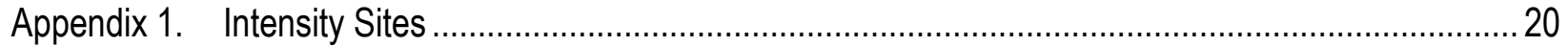

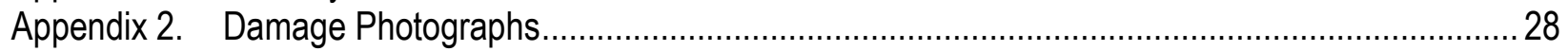

\section{Figures}

1. Location map showing population centers in northeastern California where the Canyondam

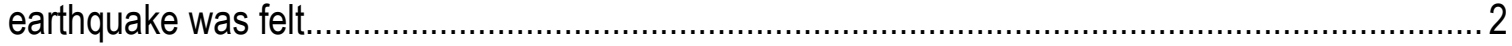

2. Map showing the tectonic setting of the Canyondam earthquake ............................................. 4

3. Map showing geologic setting of the Canyondam earthquake on May 23, 2013 .......................... 6

4. Focal mechanism for the May 23,2013 , Canyondam earthquake determined by inverting the longperiod waveforms at five regional stations located 80-250 kilometers from the epicenter. .............. 7

5. Map showing aftershocks from the May 23, 2013, Canyondam earthquake relocated using a double difference analysis. .................................................................................................. 8

6. Slip model for May 23, 2013, Canyondam earthquake determined by fitting displacement waveforms ...............................................................................................................

7. Map showing route of the search for surface rupture from the May 23, 2013, Canyondam

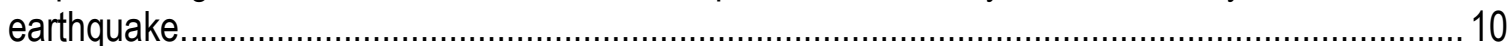

8. "Did You Feel It" (DYFI) ZIP-Code map for the area around Lake Almanor................................... 12

9. Map showing the May 23, 2013, Canyondam earthquake isoseismal distribution map for the area surrounding Lake Almanor ................................................................................................ 17

\section{Tables}

1. Modified Mercalli Intensity descriptions used to assign intensity from interviews, field observations, and damage reports. 


\title{
Faulting, Damage, and Intensity in the Canyondam Earthquake of May 23, 2013
}

\author{
By K. Chapman, ${ }^{1}$ M.B. Gold, ${ }^{1}$ John Boatwright, ${ }^{1}$ J. Sipe, ${ }^{2}$ V. Quitoriano, ${ }^{1}$ D. Dreger, ${ }^{3}$ and Jeanne Hardebeck ${ }^{1}$
}

\begin{abstract}
On Thursday evening, May 23, 2013 (0347 May 24 UTC), a moment magnitude $\left(\mathrm{M}_{\mathrm{w}}\right)=5.7$ earthquake occurred northeast of Canyondam, California. A two-person team of U.S. Geological Survey scientists went to the area to search for surface rupture and to canvass damage in the communities around Lake Almanor. While the causative fault had not been identified at the time of the field survey, surface rupture was expected to have occurred just south of Lake Almanor, approximately 2-4 kilometers south of the epicenter. No surface rupture was discovered. Felt intensity among the communities around Lake Almanor appeared to vary significantly. Lake Almanor West (LAW), Lake Almanor Country Club (LACC), and Hamilton Branch (HB) experienced Modified Mercalli Intensity $(\mathrm{MMI}) \geq 7$, whereas other communities around the lake experienced $\mathrm{MMI} \leq 6$; the maximum observed intensity was MMI 8, in LAW. Damage in the high intensity areas consisted of broken and collapsed chimneys, ruptured pipes, and some damage to foundations and to structural elements within houses. Although this shaking damage is not usually expected for an $M_{w} 5.7$ earthquake, the intensities at Lake Almanor Country Club correlate with the peak ground acceleration (38 percent g) and peak ground velocity (30 centimeters per second) recorded by the California Strong Motion Instrumentation Program accelerometer located at the nearby Lake Almanor Fire Station. The intensity distribution for the three hardest hit areas (LAW, LACC, and HB) appears to increase as the azimuth from epicenter to the intensity sites approaches the fault strike. The small communities of Almanor and Prattville on the southwestern shore of Lake Almanor experienced somewhat lower intensities. The town of Canyondam experienced a lower intensity as well, despite its location up-dip of the earthquake rupture. This report contains information on the earthquake itself, the search for surface rupture, and the damage we observed and compiled from other sources.
\end{abstract}

\section{Introduction}

At 8:47 p.m. on Thursday, May 23, 2013 (0347 May 24 UTC), a moment magnitude $\left(\mathrm{M}_{\mathrm{w}}\right) 5.7$ earthquake occurred in Plumas County, California, just southeast of Lake Almanor (see figs. 1 and 2). The earthquake was felt as far away as Redding (120 kilometers [km] west-northwest of the epicenter), Reno (130 km southeast), and Sacramento (180 km south-southwest).

\footnotetext{
${ }^{1}$ U.S. Geological Survey

${ }^{2}$ Plumas County Office of Emergency Services
} 


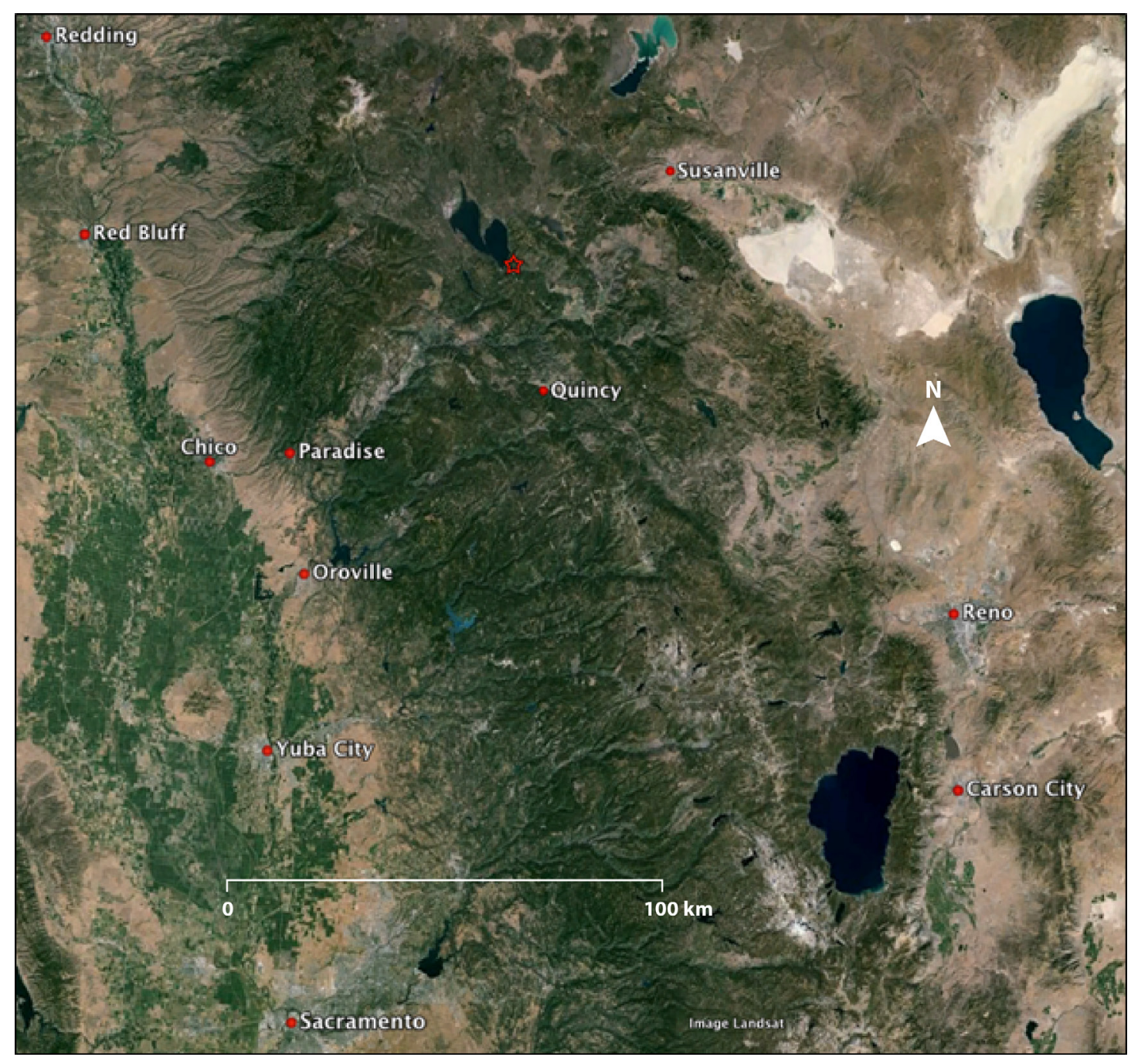

Figure 1. Location map showing population centers in northeastern California where the Canyondam earthquake was felt. The earthquake epicenter indicated by the open red star.

News reports described damaged chimneys, broken water pipes, and rock falls on roads around Lake Almanor. The "Did You Feel It?" (DYFI) Web site (Wald and others, 1999; Wald and others, 2011) obtained a maximum Community Decimal Intensity (CDI) of 7.7 for the earthquake. On June 2428,2013 , the first two authors of this paper conducted a field survey with two goals: (1) to locate any surface faulting and (2) to canvass the communities around Lake Almanor to complement the DYFI intensity reports. We were unable to discover any surface faulting, but we found the strongest earthquake damage occurred in three separate communities around the lake. The communities of Lake Almanor Country Club (LACC) and Lake Almanor West (LAW) are located on a narrow peninsula in the middle of the lake and on the western shore of the lake, respectively. The community of Hamilton Branch (HB) is located at the northeast corner of the lake. Damage in these communities consisted of chimney cracking or collapse, cracked foundations, and ruptured pipes; a few houses shifted on their foundations and sustained damage to structural elements.

We conducted 54 interviews in the communities around Lake Almanor. During our field survey, we were told that the Plumas County Office of Emergency Services (PCOES) had asked homeowners to 
describe earthquake damage to their houses and to estimate the cost of repair. The survey consisted of an online or handwritten form in which homeowners were asked to briefly describe the damage their houses sustained and to estimate the cost of the damage. PCOES provided us with the 63 damage reports they had collected. Combining these two datasets with the geocoded DYFI reports yielded an aggregate of 171 geolocated intensity sites around Lake Almanor and in towns to the east and south of the lake. While these intensity sites are sparse in some of the less populated areas, they are dense in the communities with the most damage and help to constrain the isoseismal distribution within $20 \mathrm{~km}$ of the epicenter.

\section{Regional Seismicity}

On June 28, 1975, a sequence of earthquakes began near Oroville, Calif., culminating in an $\mathrm{M}_{\mathrm{d}}$ 4.7 foreshock $\left(\mathrm{M}_{\mathrm{d}}\right.$ is a magnitude estimated from the coda duration) and an $\mathrm{M}_{\mathrm{w}} 5.7$ mainshock on August 1, 1975 (Morrison and others, 1976). The mainshock epicenter was $12 \mathrm{~km}$ southwest of the Oroville Dam, a zoned earth-filled dam completed in 1967 (Department of Water Resources, 2009). The mainshock had a predominantly normal faulting mechanism (Hart and others, 1977). The earthquake produced the first recorded surface faulting in the western foothills of the Sierra Nevada. Fresh fractures in the ground were observed in a 3.8-km-long north- to north-northwest-trending zone.

In the 38 years between the Oroville sequence in 1975 and the Canyondam sequence in 2013, 17 4.0 $\leq \mathrm{M}_{\mathrm{w}}<4.5$ earthquakes, $64.5 \leq \mathrm{M}_{\mathrm{w}}<5.0$ earthquakes, and $35.0 \leq \mathrm{M}_{\mathrm{w}}<5.5$ earthquakes have occurred in the northern Sierra Nevada/southern Cascade Range region. Thus, moderate to large earthquakes are relatively infrequent. The $\mathrm{M}_{\mathrm{w}} 4.7$ Whitehawk earthquake, a strike-slip earthquake that occurred near Sierraville on October 27, 2011, was the most recent moderate-size earthquake in the region.

Norris and others (1997) determined the three Lassen earthquake sequences that occurred in 1936, 1945-47, and 1950 were tectonic in origin and not caused by the Lassen Volcanic Center, based upon frequency-magnitude statistics and spatial and temporal clustering in the sequences. They reread original records to determine source locations and duration magnitudes for the earthquakes. The largest earthquakes in the 1946 and 1950 sequences were estimated to be $\mathrm{M}_{d} 5.0$ and $\mathrm{M}_{\mathrm{d}} 5.5$, respectively.

In their compendium of historical California earthquakes, Toppozada and others (1981) include a sequence of four $\mathrm{M} \sim 6$ earthquakes that occurred in the northern Sierra Nevada/southern Cascade Range region from 1875 to 1889 . The largest of these events was the $1888 \mathrm{M} \sim 6.2$ Mohawk Valley earthquake. The isoseismal distributions for the 1885 and 1889 earthquakes near Susanville are roughly similar to the DYFI map for the Canyondam earthquake. We have not plotted these isoseismals because the difference in data gathering and presentation between the older isoseismal maps and the newer DYFI maps make graphical comparisons difficult.

Parallels can be drawn between the $\mathrm{M}_{\mathrm{w}} 5.7$ Canyondam earthquake and the $1991 \mathrm{M}_{\mathrm{L}} 5.8$ Sierra Madre earthquake $\left(\mathrm{M}_{\mathrm{L}}\right.$ is a magnitude estimated from the peak motions observed on regional seismographs). Both events caused more damage than expected for their magnitude, and neither produced surface rupture. The mainshock epicenter of the Sierra Madre earthquake was $15 \mathrm{~km}$ north of the community of Sierra Madre, near Los Angeles, in the San Gabriel Mountains. It occurred on a section of the Clamshell-Sawpit Canyon Fault, a reverse fault splay of the Sierra Madre Fault Zone (Hauksson, 1994).

There were 100 recorded injuries in the Sierra Madre earthquake, 1 direct fatality from a steel beam falling on a woman, and 1 indirect fatality from a heart attack. There was only one reported injury from the Canyondam earthquake. Both earthquakes produced MMI 7 intensities: there were many collapsed and damaged chimneys, broken windows and pipes, and cracked foundations. Older buildings, 
likely built before 1975, suffered more damage in the Sierra Madre earthquake (Stover and Reagor, 1991).

\section{Regional Geology and Tectonics}

Lake Almanor lies at the junction of three tectonic regions: Cascadian subduction, Basin and Range extension, and Sierra Nevada uplift (fig. 2). To the north, the Juan de Fuca Plate subducts under North America and drives the volcanism seen in the Cascade Range. In its northwest corner, there is a gradual transition from normal faulting to oblique and strike-slip faulting within the Basin and Range Province. Although the history of uplift in the Sierra Nevada is complex and still under debate (Putirka and Busby, 2011), faulting within the Walker Lane dominates current tectonic activity (Faulds and others, 2005).

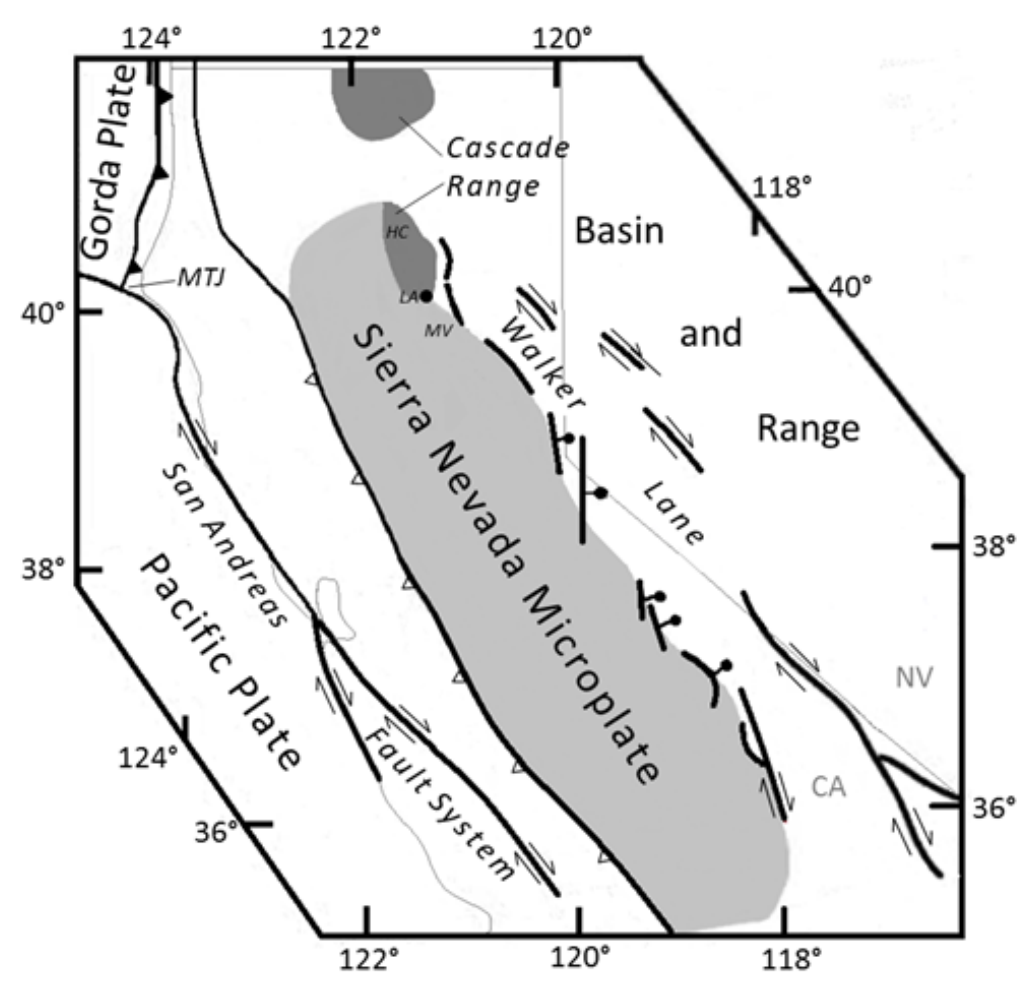

Figure 2. Map showing the tectonic setting of the Canyondam earthquake. LA, Lake Almanor; MV, Mohawk Valley Fault Zone; HC, Hat Creek Graben; MTJ, Mendocino Triple Junction. Figure modified from Wakabayashi and Sawyer, 2001.

The extent of these tectonic regions is determined by the northward-migrating Mendocino Triple Junction (Putirka and others, 2012). Subduction, and therefore activity within the Cascade Volcanic Arc, is truncated from the south as the Mendocino Triple Junction moves north. The region of transform faulting and extension expands to the north with the Mendocino Triple Junction as a result of the release of the compressional forces derived from the subducting Juan de Fuca Plate (Putirka and others, 2012).

The Walker Lane is a system of kinematically linked dextral and normal faults that runs from the Mojave region of California through the Oregon-California border (Unruh, 1995). Geodetic studies suggest that it accommodates 5-25 percent of the movement between the Pacific and North American 
Plates, moving 2-10 millimeters per year (mm/yr) (Faulds and others, 2005). It has been interpreted as an incipient transform plate boundary, as the current plate margin shifts to the east.

Although the Walker Lane system accommodates some of the current Pacific-North American motion, the Sierra Nevada microplate is the main control on the orientation and movement within the Walker Lane in the region around Lake Almanor (fig. 1). The counterclockwise rotation of the Sierra Nevada microplate is the source of a distributed sense of shear in the region, oriented at approximately $304^{\circ}$ (Unruh and others, 2003). Within this zone of distributed shear, Unruh and others (2003) propose that the faults around Lake Almanor serve as a transition zone between the Mohawk Valley Fault Zone and Hat Creek graben (fig. 2). Southeast of Lake Almanor, the Mohawk Valley Fault Zone is characterized primarily by en echelon left-stepping right-normal oblique faults oriented subparallel to the regional shear. To the north, the Hat Creek graben is characterized by extension along a fault striking approximately $330-350^{\circ}$.

Unruh (1995) argues that the type of movement on faults in this area, strike-slip or normal, is a function of their orientation. Faults that are aligned parallel to the regional shear are primarily strikeslip. As fault orientation rotates to the north, owing to control by preexisting Paleozoic and Mesozoic structures within basement rocks, the normal component of movement on the fault becomes more pronounced. This trend is exhibited by the faults around Lake Almanor, including the fault that the earthquake ruptured (see next section).

The geologic setting around Lake Almanor (fig. 3) is marked by an abrupt geologic transition. To the south of the lake are metasedimentary and intrusive rocks associated with the Sierra Nevada; these rocks are Paleozoic to Mesozoic in age (Sawyer, 1997). The regional structural fabric, with an average orientation of $330^{\circ}$, provides the previously mentioned control on fault orientation and causes faults to deviate from the regional shear of $304^{\circ}$ (Unruh and others, 2003). The Laramide orogeny in the Late Cretaceous-early Paleocene initiated the Sierra Nevada uplift to expose these rocks. To the north, Tertiary and Quaternary basalts originating from the Lassen Volcanic Center to the northwest and Modoc Plateau to the east-northeast overlie the Sierra Nevada basement (Sawyer, 1997). We note that most of the communities situated around Lake Almanor are sited either on Sierra Nevadan metasediments or Tertiary and Quaternary basalts: the two exceptions are Chester and Greenville, both of which are sited on Quaternary sediments. 


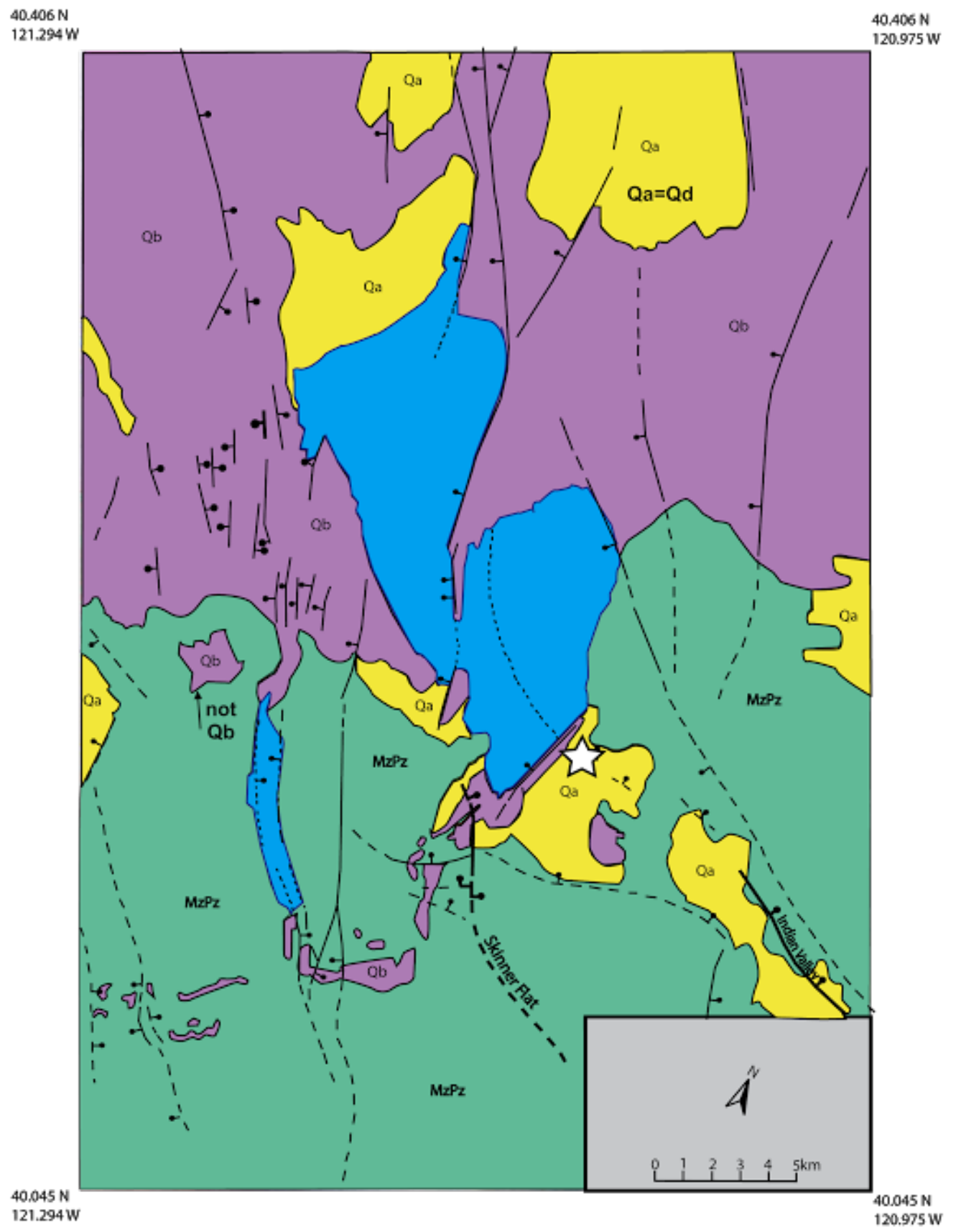

Figure 3. Map showing geologic setting of the Canyondam earthquake on May 23, 2013. Green units, MesozoicPaleozoic Sierra Nevadan basement. Purple units, Tertiary and Quaternary Cascade Range volcanics. Yellow units, unconsolidated Quaternary sediments. Modified from Sawyer (1997). 


\section{Earthquake Mechanism, Fault, and Rupture Extent}

The focal mechanism for the earthquake obtained by inverting the long-period waveforms at five regional stations for the moment tensor is shown in figure 4 . The mechanism is mixed, approximately two-thirds strike-slip and one-third normal faulting, with a moment magnitude of $\mathrm{M}_{\mathrm{w}} 5.72$ and a centroid depth of $8 \pm 3 \mathrm{~km}$. We used a double difference analysis to relocate the mainshock and aftershocks. We note that this relocation was greatly aided by the deployment of three NetQuake instruments in the epicentral area 2 days after the mainshock. The plot of the aftershock relocations (fig. 5) confirms that the nodal plane striking at $292^{\circ}$ and dipping $70^{\circ}$ to the northeast is the fault plane. The aftershocks are confined to a relatively small distance $(\sim 10 \mathrm{~km})$ along strike: there are very few aftershocks shallower than $4 \mathrm{~km}$ on the updip projection of the fault, which strongly suggests that the rupture did not extend to the surface.

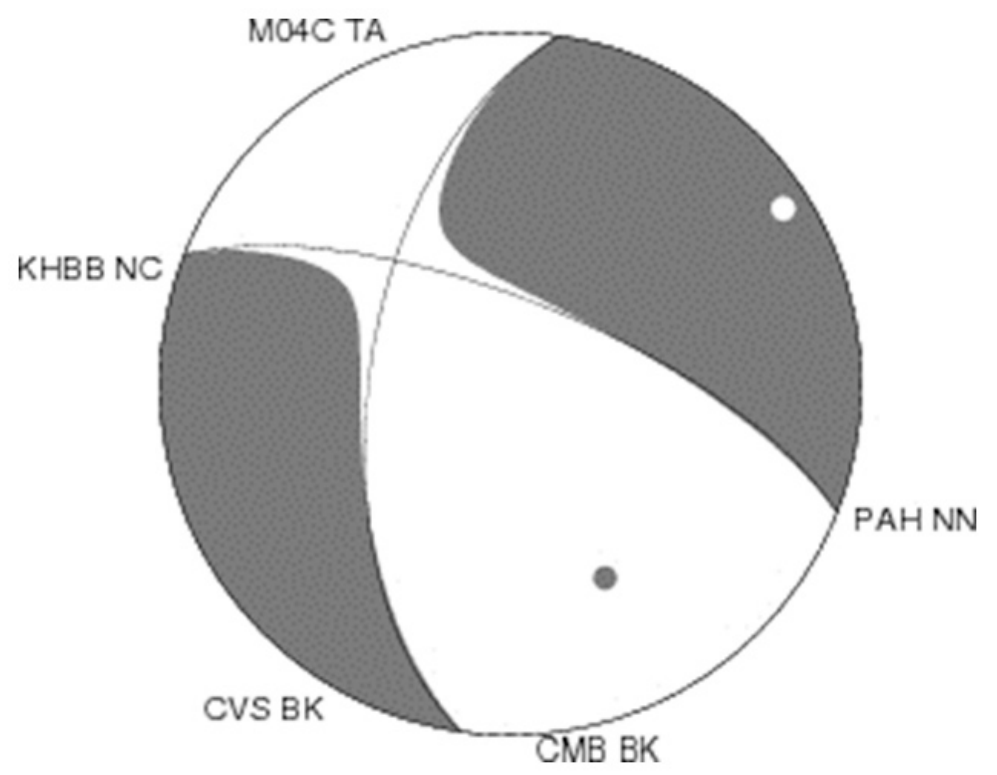

Figure 4. Focal mechanism for the May 23, 2013, Canyondam earthquake determined by inverting the longperiod waveforms at five regional stations located 80-250 kilometers from the epicenter. Azimuths to the regional stations are labeled. The white and gray dots indicate the T and P axes of the focal mechanism, respectively. 


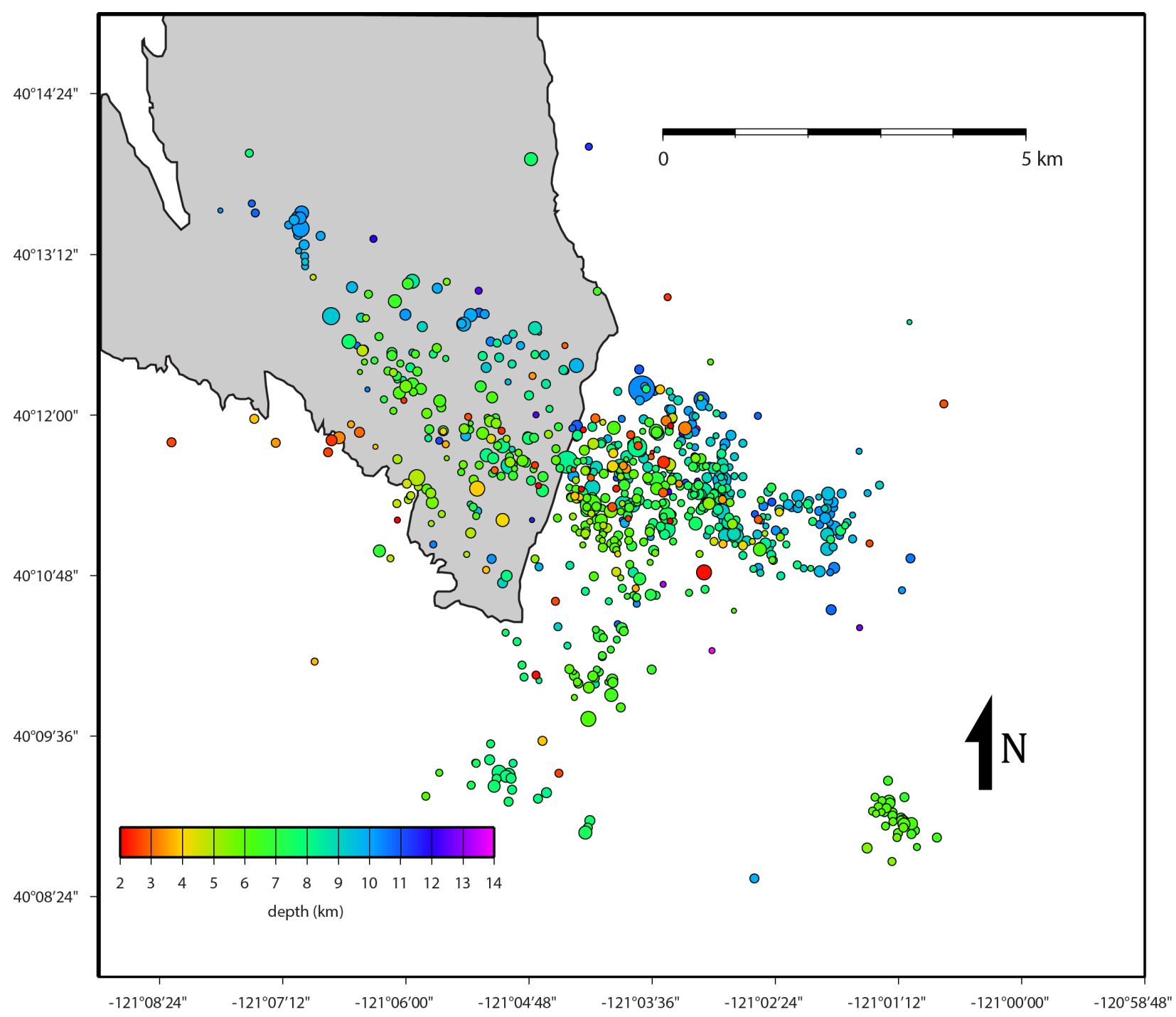

Figure 5. Map showing aftershocks from the May 23, 2013, Canyondam earthquake relocated using a double difference analysis. These locations confirm the nodal plane striking at $292^{\circ}$ and dipping $70^{\circ}$ to the northeast as the fault plane. Lake Almanor is indicated by the gray area.

We determined the distribution of slip by inverting displacement waveforms from the five regional seismograms together with the displacement waveforms obtained from the accelerogram recorded at the Lake Almanor Fire Station. We found that the earthquake ruptured updip, from 11 to 4 $\mathrm{km}$ depth, in a relatively narrow strip (fig. 6). The rupture velocity was set to 80 percent of the shearwave velocity for the slip inversion. 


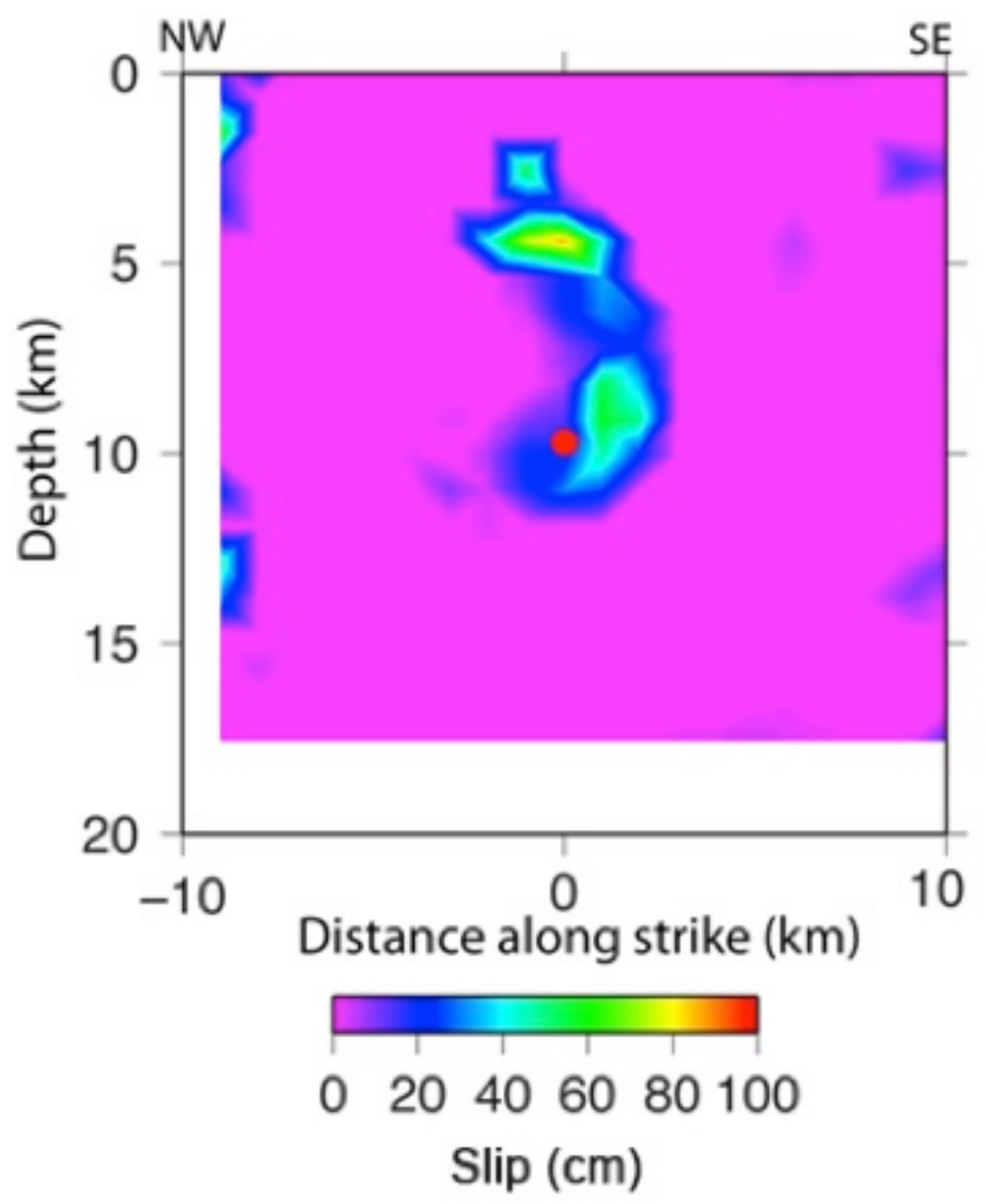

Figure 6. Slip model for May 23, 2013, Canyondam earthquake determined by fitting displacement waveforms. The inversion assumes a constant rupture velocity equal to 80 percent of the shear-wave velocity. The earthquake ruptured updip in a narrow strip from 11 to $4 \mathrm{~km}$ depth. The red dot indicates the earthquake hypocenter.

\section{Search for Surface Rupture}

At the time of the field reconnaissance to Lake Almanor, the best estimate of where the fault might daylight was 1-3 km south of Lake Almanor, 2-4 km south of the epicenter. John Parrish (California Geological Survey) speculated that the earthquake occurred on an extension of the Indian Valley Fault (Merriam, 2013), while Pat Muffler (U.S. Geological Survey [USGS], written commun., May 28, 2013) proposed that the Skinner Flat Fault was a likely candidate. The route we followed in our search for surface rupture, shown in figure 7, attempted to cover as much ground as possible in the area where the fault was estimated to daylight. This driving route intersected the Skinner Flat Fault in multiple locations. Dirt and gravel logging roads, many of which were impassable, provided the only access in the area. Almost all of the accessible land was covered by a shallow layer of soil covered by pine needles (pine duff), making it difficult to find the geology, let alone any surface faulting. We found no surface faulting during our reconnaissance, although the disturbance of the ground cover would have had to be substantial to allow us to identify surface faulting. Generally, $\mathrm{M}_{\mathrm{w}}<6$ strike-slip earthquakes do not produce surface faulting, although the normal faulting $\mathrm{M}_{\mathrm{w}} 5.7$ Oroville earthquake did. Along the 
southern part of the route, we found numerous rocks strewn on the road that could have been rockfalls caused by the earthquake.

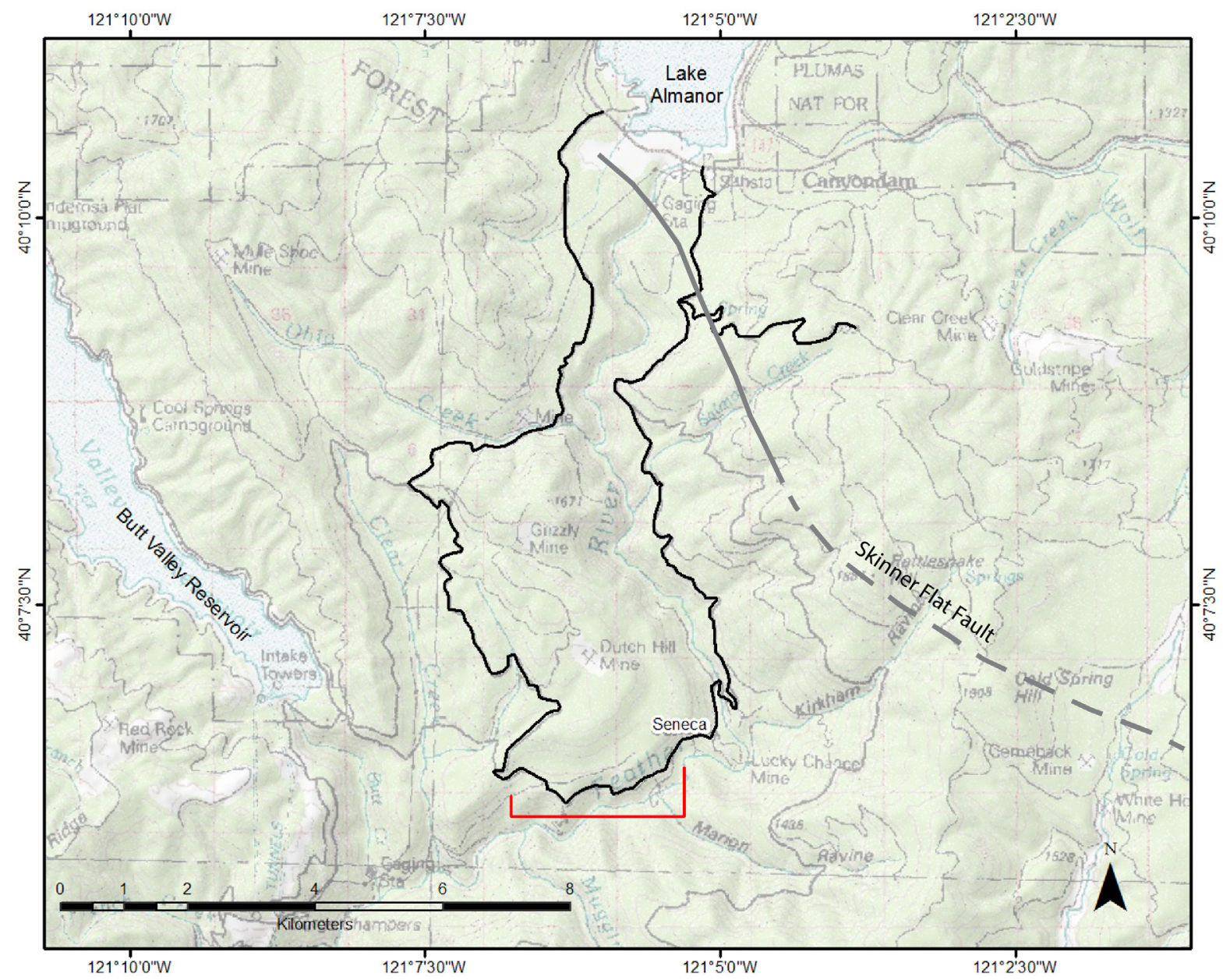

Figure 7. Map showing route of the search for surface rupture from the May 23, 2013, Canyondam earthquake. The solid gray line shows the location of the surface trace of the Skinner Flat Fault; the dashed line is the inferred trace. No surface faulting was found. The red bracket shows the location of rock falls possibly caused by the earthquake.

\section{Postearthquake Damage Assessment}

We conducted our field survey one month after the earthquake. We interviewed residents and businesses in the communities surrounding Lake Almanor and photographed unrepaired damage. Houses in this area are almost all wood-frame, and many have brick or stone chimneys. Our survey focused on the communities that suffered the most damage: Lake Almanor Country Club (LACC) and Lake Almanor West (LAW). We also conducted interviews in Hamilton Branch (HB), East Shore, Lake Almanor Peninsula (LAP), Canyondam, Chester, Westwood, Almanor, Prattville, Greenville, Crescent Mills, and Twain. We made a particular effort to assess damage near the two dams in the area: Almanor Dam and Butt Valley Dam. 
We began our surveys in areas that reported high intensities to "Did You Feel It" (DYFI), knocking on the doors of houses that appeared occupied. We asked each person we interviewed if they had filled out a DYFI report to avoid double counting. After we completed the field survey, we contacted the Plumas County Office of Emergency Services (PCOES) and obtained copies of the damage reports that they had gathered from residents and local fire departments. The site locations and intensity assignments are gathered in Appendix 1. Our 54 interviews are compiled in table 1-1, the 63 PCOES reports are compiled in table 1-2, and the 50 nearby geocoded DYFI reports are compiled in table 1-3. Figure 8 shows the DYFI ZIP-Code map for the area around Lake Almanor with the locations of the geocoded DYFI reports, interviews, and PCOES reports superimposed. There were 31 DYFI responses without addresses in the nearby ZIP Codes.

In our canvassing, we were directed toward the areas and homes with the most severe damage, although many residents were not at home. Photographs of the earthquake damage, many taken by residents and volunteered to us, are gathered in Appendix 2. This damage-centric reporting is characteristic of historical newspaper reports but differs from the more random sampling of DYFI. Because LACC and LAW are resort communities, many residents were not present when the earthquake occurred and did not submit DYFI reports, so the DYFI dataset is relatively small.

Each of these three datasets (interviews, PCOES, and DYFI) is incomplete. Most residents didn't fill out a DYFI online report or a PCOES damage report, and we had difficulty reaching residents for interviews. Remarkably, there is only one apparent overlap (two sites located within 40 feet) between these three datasets, a statistical anomaly that implies that these three datasets are not a complete account of the earthquake damage around Lake Almanor. 


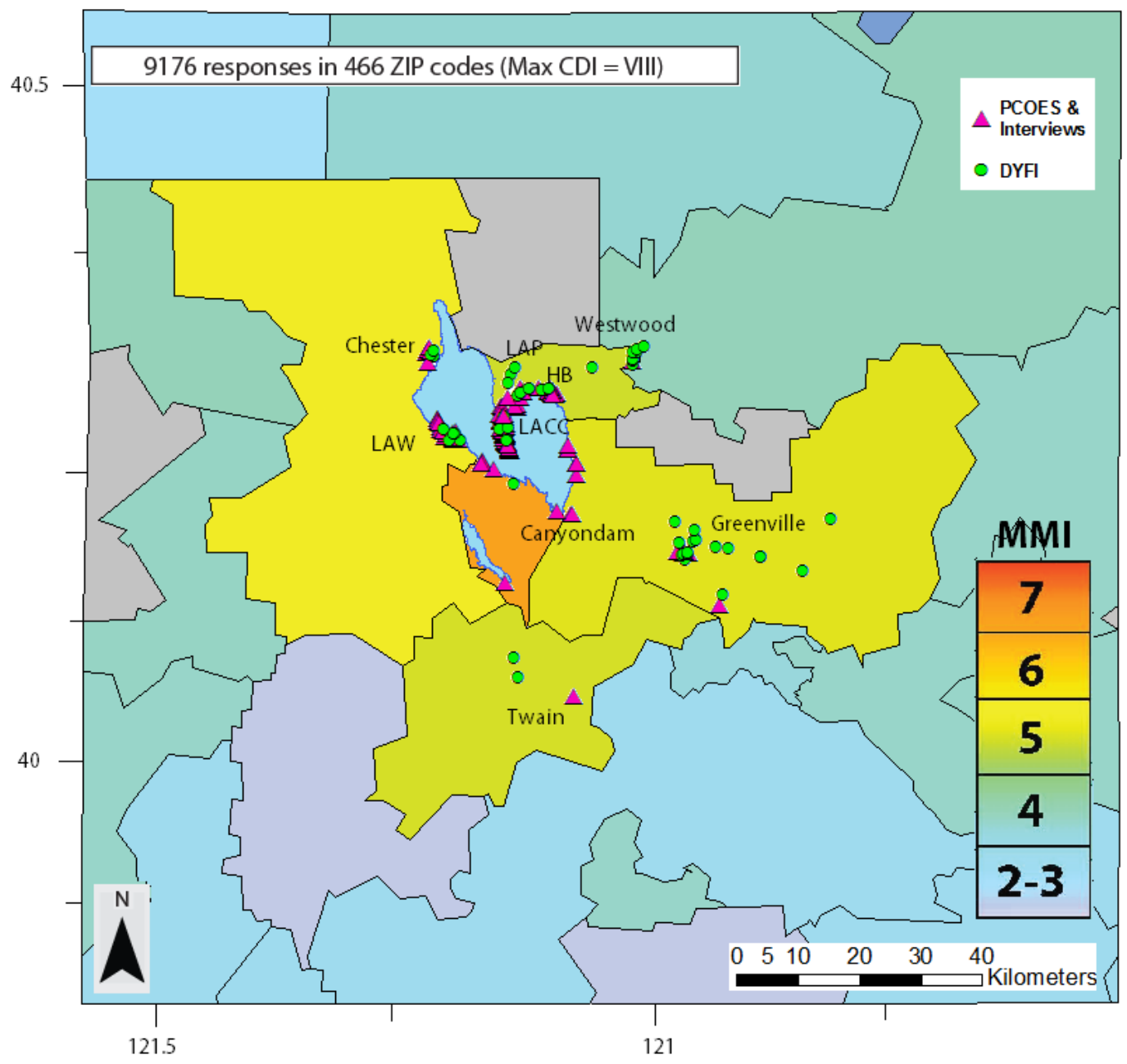

Figure 8. "Did You Feel It" (DYFI) ZIP-Code map for the area around Lake Almanor. Locations for our interviews (table 1-1), the Plumas County Office of Emergency Services (PCOES) reports (table 1-2), and the geocoded DYFI reports (table 1-3) are superimposed on the map.

In tables 1-1 and 1-2, we interpret the damage and felt reports using Richter's (1958) Modified Mercalli Intensity (MMI) Scale. A shortened version of Richter's MMI Scale is given below in table 1. It was apparent in our survey that chimney damage represents an important benchmark between the minor damage of drywall and masonry cracking at MMI 6 and the major structural damage to woodframe houses at MMI 8. This interpretation coincides with Stover and Coffman's (1993) reclassification of chimney damage as MMI 7, which is incorporated in the online DYFI questionnaire. DYFI generates a Community Decimal Intensity (CDI) based on user responses. We checked these CDIs against the respondent comments, discarding two CDIs that did not agree with the effects described by the respondents (table 1-3, entries 16 and 17). 
Table 1. Modified Mercalli Intensity descriptions used to assign intensity from interviews, field observations, and damage reports.

[Reprinted from Richter (1958). Boldface italics indicate shaking effects reported in interviews and DYFI comments. Square brackets indicate Stover and Coffman's (1993) reclassification of chimney damage as MMI 7]

\begin{tabular}{|c|c|}
\hline MMI & Description \\
\hline 1 or I & Not felt. Marginal and long-period effects of large earthquakes. \\
\hline 2 or II & Felt by persons at rest, on upper floors, or favorably placed. \\
\hline 3 or III & $\begin{array}{l}\text { Felt indoors. Hanging objects swing. Vibration like passing of light trucks. Duration estimated. May not be } \\
\text { recognized as an earthquake. }\end{array}$ \\
\hline 4 or IV & $\begin{array}{l}\text { Hanging objects swing. Vibration like passing of heavy trucks; or sensation of a jolt like a heavy ball striking } \\
\text { the walls. Standing motorcars rock. Windows, dishes, doors rattle. Glasses clink. Crockery clashes. In the } \\
\text { upper range of IV wooden walls and frame creak. }\end{array}$ \\
\hline 5 or $\mathrm{V}$ & $\begin{array}{l}\text { Felt outdoors; direction estimated. Sleepers awakened. Liquids disturbed, some spilled. Small unstable } \\
\text { objects displaced or upset. Doors swing, close, open. Shutters, pictures move. Pendulum clocks stop, start, } \\
\text { and change rate. }\end{array}$ \\
\hline 6 or VI & $\begin{array}{l}\text { Felt by all. Many people frightened and run outdoors. Persons walk unsteadily. Windows, dishes, and } \\
\text { glassware broken. Knickknacks, books, etc... knocked off shelves. Pictures knocked off walls. } \\
\text { Furniture moved or overturned. Weak plaster and weak masonry cracked. Small bells ring (church, } \\
\text { school). Trees, bushes shaken visibly or heard to rustle. }\end{array}$ \\
\hline 7 or VII & $\begin{array}{l}\text { Difficult to stand. Noticed by drivers of motorcars. Furniture broken. Damage to weak masonry, including } \\
\text { cracks. [Chimneys broken or collapsed.] Fall of plaster, loose bricks, stones, tiles, cornices (also unbraced } \\
\text { parapets and architectural ornaments). Some cracks in masonry of average construction. Waves on ponds; } \\
\text { water turbid with mud. Small slides and caving in along sand or gravel banks. Large bells ring. Concrete } \\
\text { irrigation ditches damaged. }\end{array}$ \\
\hline 8 or VIII & $\begin{array}{l}\text { Steering of motorcars affected. Damage to masonry C; partial collapse. Some damage to masonry B; none to } \\
\text { masonry A. Fall of stucco and some masonry walls. Fall of factory stacks, monuments, towers, and } \\
\text { elevated tanks. Frame houses moved on foundations if not bolted down; loose panel walls thrown out. } \\
\text { Decayed piling broken off. Branches broken from trees. Changes in flow or temperature of springs and } \\
\text { wells. Cracks in wet ground and on steep slopes. }\end{array}$ \\
\hline
\end{tabular}

Richter (1958) classifies rock falls as MMI 7. Anna Sojouner of the California Department of Transportation (written commun., February 13, 2014) provided the locations of a rock more than a cubic yard that was removed from Highway 89 near Prattville and of a small slide across Highway 70 near Twain. These sites were added to table 1-1. Bill Page of PG\&E (oral commun., July 23, 2013) reported that Prattville-Butt Reservoir Road was heavily obstructed by rock falls after the earthquake but did not give a specific location.

The most severe damage that we observed occurred in Lake Almanor West, where one house was shifted on its foundation, floor joists of another house were damaged, and three houses had displaced or racked cripple walls. We interpret this structural damage to indicate MMI 8. Five other houses in LAW reported plumbing or gas-line breaks inside their houses: this effect is not described in Richter's (1958) scale, nor is it included in the online DYFI questionnaire. After discussions with Jim 
Dewey at USGS in Golden, Colorado, we interpreted these pipe breaks as MMI 7.5, as this effect was only reported in the most strongly damaged communities.

These strong shaking effects - chimneys damaged, some houses shifted on their foundations, and some internal pipe breaks - resemble the damage reported by Stover and Reagor (1991) for the 1991 Sierra Madre earthquake. This $\mathrm{M}_{\mathrm{w}} 5.6$ thrust earthquake (Hauksson, 1994) produced pockets of strong damage in the cities of Monrovia, Sierra Madre, and Pasadena, 14-20 km from the epicenter. Stover and Reagor (1991) estimated the average intensity in these cities as MMI 7. The earthquake caused 107 injuries and 1 direct fatality, from a steel beam that fell on a woman at the Santa Anita Racetrack in Arcadia (Stover and Reagor, 1991).

The locations described below are arranged in a counterclockwise order around Lake Almanor, starting near the epicenter. Unless otherwise noted, the communities are situated on Tertiary or Quaternary basalts covered by alluvium (fig. 3).

\section{Hamilton Branch and East Shore}

Hamilton Branch (HB) is a community of 272 houses split between seasonal and full-time residents. There were 2 DYFI reports (CDI 5.8 and 7.7) and 13 PCOES reports from HB. Twelve of the PCOES reports cited chimney damage, and one cited a broken water pipe. Generally, houses farther from the water experienced more damage than those along the shore.

The East Shore is a resort area consisting of approximately 240 houses situated near the highway running along the eastern shore of the lake. There were no DYFI reports from this area, and in our one interview, the resident only reported items falling off shelves. There were four reports of chimney damage submitted to PCOES. Few residents were home during our field study.

\section{Lake Almanor Country Club and Lake Almanor Peninsula}

Lake Almanor Country Club (LACC) is a gated resort community of approximately 1,100 houses and a golf course on the central peninsula that bisects Lake Almanor. The LACC fire department houses an accelerometer maintained by the California Strong Motion Instrument Program. The Fire Station itself was slightly damaged (table 1-2, item 23). All residents who were present felt shaking to some degree, and most reported that items fell off shelves or walls. There were 4 DYFI reports (CDI 5.3-6.8) and 30 damage reports submitted to PCOES, 27 of which included chimney damage. We found many damaged chimneys that had not been reported to PCOES. Houses built in the 1960s and 1970s were more likely to suffer total chimney collapse, whereas more modern houses either did not have brick chimneys or only suffered moderate chimney damage. Damage decreased with distance from the tip of the peninsula but remained high along both shorelines.

South of the golf course, many houses had tarps covering damaged or collapsed chimneys. In one house on Peninsula Drive, which runs along the eastern shore of the peninsula, the fireplace collapsed inside the house, breaking the homeowner's leg and damaging furniture. The chimney collapsed above the roofline, and bricks in the remaining chimney had separated (table 1-1, item 5). The porch had separated a few inches from the house. This injury was the only reported injury caused by the earthquake. Photographs of the damage to this house are shown in figures 2-1 to 2-3.

The greatest concentration of damaged or collapsed chimneys was on Lassen View Drive, which runs along the western shore of the peninsula. In one house, the chimney fell through the porch, leaving a hole and causing some roof damage (table 1-1, item 22; figs. 2-4 to 2-6). The cinder block foundation was cracked in several places (figs. 2-7 and 2-8), and there were many bent doorframes. Several other residents reported shifted or bent doorframes, owing to settling. There was one report of a broken gasline on this street, which was repaired the next day. There was also a report of a fissure that opened 
between Lassen View Drive and the shoreline (table 1-1, item 14). The fissure extended approximately 90 meters through three properties and was 1.5 inches at the widest. This was the only reported instance of ground cracking.

The shaking was less severe in the northern section of LACC. Residents in this area only reported some heavy objects falling off shelves and walls, as well as hairline drywall cracks. There were no collapsed chimneys and few lightly damaged chimneys. A coupling broke on the municipal water tank by the Clifford Drive gate, spilling 50,000 gallons of water before being shut down by the LACC Mutual Water Company (table 1-1, item 28; fig. 2-9). This was the only major water line break in LACC. Figures in appendix 2 show collapsed and damaged chimneys in LACC.

In Lake Almanor Peninsula (LAP), a smaller community of approximately 230 houses situated northeast of LACC, there were 6 DYFI reports (CDI 2.7-6.5). In interviews, residents reported shaking and items falling from shelves but no chimney or structural damage. The local newspaper, Plumas County News, printed a photograph of Wally's Peninsula Market after the event because of the large number of items that fell into the aisles (May 2013). The damage at this market is graded as a moderate disturbance in Nason's (1984) food store intensity scale. No reports of damage were submitted to PCOES from this community.

\section{Chester and Westwood}

In Chester, a town of approximately 900 houses, there were 2 DYFI reports (CDI $\sim 6)$ of moderate shaking. $\mathrm{A} \mathrm{CDI}=2.0$ report was excluded from the dataset because the respondent reported the walls were moving 1-2 feet and that she had leapt up and held a flat-screen TV to keep it from falling. A CDI of 2.0 indicates that the shaking was barely felt. We observed a damaged chimney at a Catholic church on Main Street where the top course of bricks had been broken (table 1-1, item 34). No damage from Chester was reported to PCOES. Chester is underlain by Quaternary sediments.

Westwood is situated $11 \mathrm{~km}$ northeast of LACC and consists of approximately 850 houses. There were seven DYFI reports; the CDIs ranged from 3.8 to 6.1. Many residents reported items falling off shelves. There was also a DYFI report of water sloshing from a fish tank that was excluded because DYFI assigned a CDI of 2.0. We found one damaged chimney with a brick on the roof (table 1-2, item 35; fig. 2-15). Residents we interviewed did not know of any significant damage in the community.

\section{Lake Almanor West}

Lake Almanor West (LAW) is a resort community consisting of about 400 houses situated around a golf course. There were seven DYFI reports (CDI 6.1-7.5) and seven PCOES damage reports. The most severe shaking effects reported were three houses shifted on their foundation, three broken chimneys, and three broken water lines. There were no reports of injuries. Damage appeared worse along the shoreline and decreased somewhat with distance from the lake.

On Kokanee Trail, near the tip of the Almanor West Peninsula, one house was displaced on its cripple wall (table 1-2, item 62). At a neighboring house (table 1-1, item 41), there were several 2-mlong cracks along a paved walkway, as well as a cracked foundation, shifted doorframes, cracked sheet rock around the fireplace, and a broken pipe in the basement that caused flooding at the time of the earthquake (fig. 2-16).

On Lake Almanor West Drive, we found one house with displaced or racked cripple walls, and we were told of two others. The homeowner showed us the damage her house sustained as it settled (table 1-1, item 40). There was significant drywall cracking on the first floor, caused by settling of the upper story on the lower story. Two load-bearing laminated wooden roof beams were partially separated 
from the wall and cracked. The 640-pound freestanding fireplace shifted, causing the flue to bend and cracking the stone archway that housed it. Figures 2-17 to 2-20 show photographs of this damage.

\section{Almanor, Prattville, and Canyondam}

Despite their proximity to Lake Almanor West and Lake Almanor Country Club, the small communities of Almanor and Prattville on the southwestern shore of Lake Almanor did not suffer much damage. Many items fell off shelves, but there were no reports of chimney or structural damage. At the Plumas Pines Bar \& Cocktails in Almanor (table 1-1, item 42), an electrical pole detached from the building, and a gas line nearly separated from the kitchen broiler. The bar also reported that all the bottles on the lakeside (northeastern) wall fell, while the other bottles remained on the shelves. Prattville experienced similar shaking. One restaurant we visited lost several plates and wine glasses that fell off the shelves (table 1-1, item 44). At a nearby home, a large shelf containing glassware fell on a resident, although no injuries were reported (Plumas County News, May 2013).

There was one geocoded DYFI report (CDI 6.1) from the town of Canyondam and two DYFI reports (CDI 9.1 and 7.3) without addresses. The owner of the Quail Lodge in Canyondam reported that many items fell off shelves, including a computer and other heavy objects (table 1-1, item 46). The only other damage to the Quail Lodge was slight drywall cracking in one guest bathroom and a toppled aviary outside. Other residents of Canyondam reported similar shaking effects. Soon after the earthquake, a field team from the University of Nevada, Reno, installed a NetQuake instrument at Quail Lodge to record aftershocks.

\section{Almanor Dam and Butt Valley Dam}

Almanor Dam is located at the southern end of Lake Almanor, $3.3 \mathrm{~km}$ west of the epicenter. We interviewed PG\&E employees at the Line Station near Almanor Dam and Caltrans employees at the maintenance station in Chester about damage to the dam (table 1-1, item 47). They reported that there had been no damage to the dam itself. Caltrans reported that one bent (support column) under the bridge across the spillway was displaced by one-eighth inch. PG\&E has two accelerometers sited at Almanor Dam, both of which failed to record the earthquake.

We also went to Butt Valley Dam to look for damage or shaking effects (table 1-1, item 49). Butt Valley Dam is located at the southern end of the Butt Valley Reservoir, $11 \mathrm{~km}$ southwest of the epicenter. Along the crest of the dam, we found a possible right-lateral offset of the bolts on the guardrail (fig. 2-21), consistent with the strong (30 percent g) east-west motion recorded by the PG\&E accelerometer sited on the dam crest. Bolts were displaced in the middle of the dam, while those at either end did not appear to be affected. PG\&E reported that their field crew found the road to Butt Valley Dam blocked by rock falls after the earthquake.

\section{Greenville, Crescent Mills, and Twain}

There were 16 DYFI reports from Greenville of varying intensity (CDI 2.2-6.7). Greenville is about $11 \mathrm{~km}$ southeast of Canyondam. The Sierra Lodge (table 1-1, item 51) had a cracked window and cracked drywall (fig. 2-22), and the Evergreen Supermarket had items fall off the shelves (table 1-1, item 52). The damage in the Evergreen Supermarket corresponds to a mild disturbance in Nason's (1984) food store intensity scale. One resident reported fireplace damage and a collapsed outbuilding to PCOES (table 1-2, item 64). Greenville is underlain by Quaternary sediments.

Crescent Mills (16 km southeast of Canyondam) and Twain (17 km south-southwest of Canyondam) experienced slight shaking and had no damage. We interviewed a business owner at an 
antique store in Crescent Mills (table 1-1, item 54) who said that a bolt of fabric fell off a shelf and a general store manager in Twain (table 1-1, item 55) who reported slight shaking. The two reports (CDI 6.5 and 6.8) from Twain differ sharply from the one report (CDI 3.1) from Crescent Mills. Crescent Mills is underlain by Quaternary sediments, whereas Twain is underlain by Sierra Nevadan metasediments.

\section{Isoseismal Distribution}

To determine the intensity distribution around Lake Almanor, we assigned MMI values to each interview and PCOES report. We combined these estimates in GIS with the DYFI CDIs obtained from their web questionnaire to obtain the isoseismal map shown in figure 9. The map shows that the highest intensities are localized in Lake Almanor West (LAW) and the Lake Almanor Country Club (LACC); it also shows how the intensity increased from north to south on the Lake Almanor peninsula, especially along Lassen View Drive, which runs along the western shore of the country club. There is an element of false detail in the map that results from the GIS contouring; however, the map accurately portrays what we saw and what was reported to us.

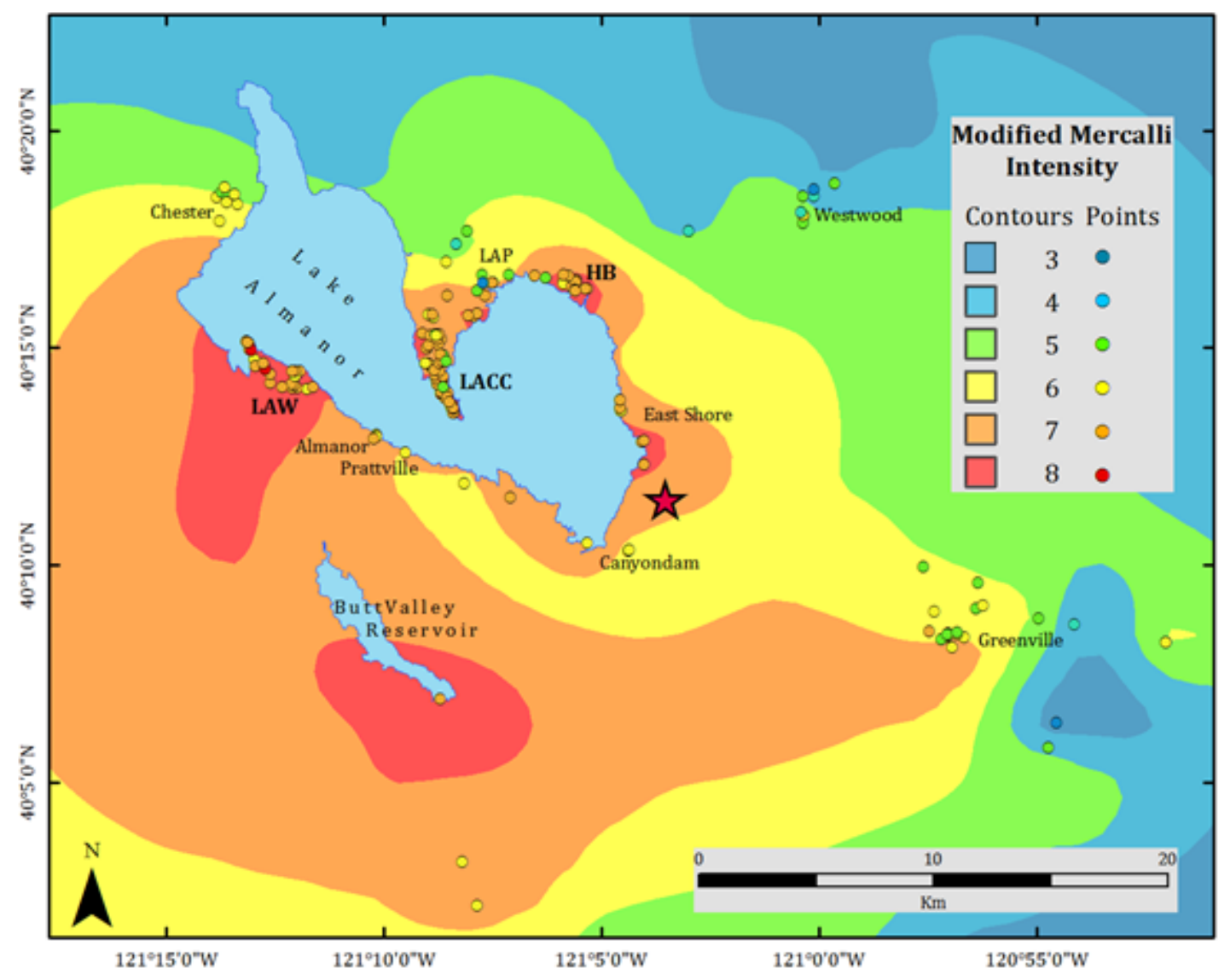

Figure 9. Map showing the May 23, 2013, Canyondam earthquake isoseismal distribution map for the area surrounding Lake Almanor. Intensity is well constrained in Lake Almanor Country Club (LACC) and adequately constrained in Lake Almanor West (LAW), Hamilton Branch (HB), Lake Almanor Peninsula (LAP), Westwood, and Chester, but poorly constrained to the north, east, and west of the lake, where there are no communities. 
The intensity is best determined in LACC, where the sites are the densest, with 58 sites and the accelerograph recording. LAW and HB are well constrained, with 17 and 10 sites, respectively, and consistent intensity estimates. Chester, LAP, and Westwood are also well constrained with 10, 8, and 7 intensity sites, respectively, and consistent intensity estimates. Greenville has 14 sites, but the intensity estimates vary from MMI 3 to 7. Almanor, Prattville, Canyondam, and East Shore have relatively few sites, but the intensities there are constrained by the presence or absence of chimney damage. Four of 5 sites within the East Shore have damaged chimneys, but no chimney damage was reported in the other communities. Butt Valley Dam is fairly well constrained with an accelerograph and a single intensity site. The intensity at Lake Almanor Dam could not be determined because we could not gauge the shaking from the slight displacement of the bent supporting the roadway. Despite the relatively few intensity sites in either Almanor or Prattville, no chimney damage was reported to us when we visited these communities, and we are confident of our intensity estimates there.

The intensity around Lake Almanor shows little falloff with epicentral distance. The closest communities, Canyondam and East Shore, suffered MMI 6-7 damage at $3 \mathrm{~km}$ epicentral distance, while HB and LACC suffered MMI 7-7.5 damage at 10 and $12 \mathrm{~km}$ epicentral distances. LAP, Westwood, and Chester suffered MMI 5-6 damage at 15, 18, and $24 \mathrm{~km}$ epicentral distances, while LAW suffered MMI 7-8 at $18 \mathrm{~km}$ epicentral distance. Although the damage suffered by the southern part of LACC appears to correlate with the damage at LAW, both Almanor and Prattville, just $2 \mathrm{~km}$ to the southwest, suffered less damage. The intensity in the strongly damaged areas increases as the azimuth from the epicenter approaches the fault strike.

If we compare the intensity distribution in figure 9 to the geologic map in figure 3 , we see that the communities with the most damage-LAW, LACC, and HB - are situated on Tertiary and Quaternary basalts, whereas Chester and Greenville are on Quaternary sediments. The geology underlying these sites implies that the highest intensities are not amplified by site response; in fact, it makes the difference in intensity between Lake Almanor West and Chester more marked. Clearly, the strong damage in LAW, the increase of damage to the south in LACC, and the somewhat isolated damage is not a result of amplification by the surficial geology. We note that these damaged areas are situated partly on ridges and hillsides, which argues against the possibility of site amplification caused by low-velocity sediments trapped beneath the basalt.

\section{Conclusions}

The $\mathrm{M}_{\mathrm{w}}$ 5.7 Canyondam earthquake caused a surprising amount of damage to well-built woodframe houses in the resort communities of Lake Almanor West, Lake Almanor Country Club, and Hamilton Branch. The most obvious damage occurred to chimneys that were broken and often collapsed, but foundations, water and gas pipes, and some structural elements of these houses were also damaged. Other communities situated around Lake Almanor were less severely damaged: Chester, Lake Almanor Peninsula, Westwood, Canyondam, and Prattville. These communities generally reported items falling from walls and shelves, cracked drywall, and cracked chimneys. The communities that suffered the strongest damage were all built relatively recently (since the 1960s) and underlain by Tertiary and Quaternary basalts, so it is unlikely that the damage can be attributed to poor construction or site amplification. 


\section{References Cited}

Department of Water Resources, 2009, California State Water Project; Information about Oroville facilities: Department of Water Resources Web site, accessed July 2013 at http://www.water.ca.gov/swp/facilities/Oroville/LakeDam.cfm.

Faulds, J.E., Henry, C.D., and Hinz, N.H., 2005, Kinematics of the northern Walker Lane; an incipient transform fault along the Pacific-North American plate boundary: Geology, v. 33, no. 6, p. 505-508.

Hart, R.S., Butler, R., Kanamori, H., 1977, Surface wave constraints on the August 1, 1975, Oroville earthquake: Bulletin of the Seismological Society of America, v. 67, no. 1, p. 1-7.

Hauksson, E., 1994, The 1991 Sierra Madre earthquake sequence in southern California; Seismological and tectonic analysis: Bulletin of the Seismological Society of America, v. 84, no. 4, p. 1058-1074.

Merriam, M., 2013, M5.7 Earthquake near Lake Almanor, California: Earthquake Engineering Research Institute, EERI Newsletter, June 2013, vol. 47, no. 6, p. 3.

Morrison, P.W., Stump, B.W., Uhrhammer, R., 1976, The Oroville earthquake sequence of 1975:

Bulletin of the Seismological Society of America, v. 66, no. 4, p. 1065-1084.

Nason, R., 1984, Food store disturbance as a seismic intensity indicator: Bulletin of the Seismological Society of America, vol. 74, no. 3, p. 987-993.

Norris, R.D., Meagher, K.L., Weaver, C.S., 1997, The 1936, 1945-47, and 1950 earthquake sequences near Lassen Peak, California: Journal of Geophysical Research, vol. 102, no. B1, p. 449-457.

Putirka, K., and Busby, C., 2011, Introduction-origin and evolution of the Sierra Nevada and Walker Lane: Geosphere, v. 7, no. 6, p. 1269-1272.

Putirka, K., Marlon, J., Cousens, B., Sharma, R., Torrez, G., Carlson, C., 2012, Cenozoic volcanism in the Sierra Nevada and Walker Lane, California, and a new model for lithosphere degradation: Geosphere, v. 8, no. 2, p. 265-291.

Richter, C., 1958, Elementary seismology: San Francisco, Freeman and Company, 768 p.

Sawyer, Tom L., 1997, Geology at Lake Almanor Dam, Plumas County, California: PG\&E Geosciences Department, p. 7-50.

Stover, C.W., and Coffman, J.L., 1993, Seismicity of the United States, 1568-1989 (Revised): U.S. Geological Survey Professional Paper 1527, 418 p.

Stover, C.W., and Reagor, B.G., 1991, Preliminary isoseismal map for the Sierra Madre, California, Earthquake of June 28, 1991 UTC: U.S. Geological Survey Open-File Report 91-388, 16 p.

Toppozada, T.R., Real, C.R., and Parke, D.L., 1981, Preparation of isoseismal maps and summaries of reported effects for pre-1900 California earthquakes: California Division of Mines and Geology Open-File Report 81-11, 182 p.

Unruh, J.R., 1995, Late Cenozoic tectonics of great Walker Lane belt and implications for active deformation in the Almanor region, northeastern California: Quaternary geology along the boundary between the Modoc Plateau, southern Cascade Mountains, and northern Sierra Nevada, Friends of the Pleistocene, Pacific Cell Field Trip, Appendix B.

Unruh, J.R., Humphrey, J., and Barron, A., 2003, Transtensional model for the Sierra Nevada frontal fault system, eastern California: Geology, v. 31, no. 4, p. 327-330.

Wald, D., Quitoriano, V., Dengler, L., Dewey, J., 1999, Utilization of the Internet for rapid community intensity maps: Seismological Research Letters, v. 70, no. 6, p. 680-697.

Wald, D., Quitoriano, V., Worden, B., Hopper, M., Dewey, J.W., 2011, USGS “Did You Feel It" Internet-based macroseismic intensity maps: Annals of Geophysics, v. 54, no. 6, p. 688-707. 


\section{Appendix 1. Intensity Sites}

Table 1-1. Resident interview locations, descriptions, and MMl classifications.

[HB, Hamilton Branch; LACC, Lake Almanor Country Club; LAP, Lake Almanor Peninsula; LAW, Lake Almanor West; PGA, peak ground acceleration; MMI, Modified Mercalli Intensity]

\begin{tabular}{|c|c|c|c|c|c|}
\hline $\mathbf{N}$ & Latitude & Longitude & MMI & City & Notes \\
\hline 1 & 40.276 & -121.098 & 6 & HB & Glass broke when it fell out of the cupboards. \\
\hline 2 & 40.226 & -121.076 & 6.5 & HB & $\begin{array}{l}\text { A loud sound first, then things fell off shelves, pictures } \\
\text { broke, and the stove rattled. Felt lots of aftershocks. }\end{array}$ \\
\hline 3 & 40.275 & -121.098 & 5.5 & HB & No damage. Pictures shifted on walls. \\
\hline 4 & 40.226 & -121.076 & 6 & East Shore & $\begin{array}{l}\text { Things fell, picture frames moved. Like a tractor hitting } \\
\text { the house. }\end{array}$ \\
\hline 5 & 40.237 & -121.144 & 7.5 & LACC & $\begin{array}{l}\text { Fireplace exploded and broke the leg of one resident. } \\
\text { Carpet stained by blood from injury. Side porch } \\
\text { separated from house. Furniture broken from falling } \\
\text { fireplace. Broken glass and bottles. Pictures torn from } \\
\text { walls. Extensive drywall cracking. }\end{array}$ \\
\hline 6 & 40.262 & -121.148 & 6 & LACC & Pictures down, glassware fell off shelves and broke. \\
\hline 7 & 40.263 & -121.150 & 6.5 & LACC & $\begin{array}{l}\text { Stiff jolt, mirror fell leaving holes in wall from nails, } 2 \\
\text { wine glasses fell, sliding closet door came off trails. }\end{array}$ \\
\hline 8 & 40.247 & -121.144 & 5.5 & LACC & Slight drywall cracking along one window. \\
\hline 9 & 40.232 & -121.145 & 7 & LACC & $\begin{array}{l}\text { Possible roof damage, residents not home to confirm. } \\
\text { Tarp on backside of roof. }\end{array}$ \\
\hline 10 & 40.243 & -121.149 & 6 & LACC & Dry wall cracking, lamps fell. \\
\hline 11 & 40.242 & -121.148 & 6.5 & LACC & Chimney cracked. \\
\hline 12 & 40.225 & -121.140 & 7.5 & LACC & $\begin{array}{l}\text { Gas pipe ruptured from ground movement inside house, } \\
\text { chimney fell above roofline. }\end{array}$ \\
\hline 13 & 40.227 & -121.140 & 6.5 & LACC & $\begin{array}{l}\text { Top course of bricks on chimney broken off. Chimney } \\
\text { otherwise undamaged. }\end{array}$ \\
\hline 14 & 40.229 & -121.141 & 8 & LACC & $\begin{array}{l}\text { Fissure extended to neighboring lots on either side. It } \\
\text { was } 1.5 \text { inch wide at maximum and of unknown } \\
\text { depth. Approximately } 90 \text { meters running through } \\
\text { three separate properties. }\end{array}$ \\
\hline 15 & 40.231 & -121.143 & 7.5 & $\mathrm{LACC}$ & $\begin{array}{l}\text { Chimney fell above roofline, puncturing the roof. The } \\
\text { garage doors were bent and did not work. Kitchen } \\
\text { cabinets loosened, glassware destroyed. }\end{array}$ \\
\hline 16 & 40.233 & -121.145 & 7 & LACC & $\begin{array}{l}\text { Cabinets fell off wall, small foundation cracks, doors off } \\
\text { hinges and windows broken. }\end{array}$ \\
\hline 17 & 40.238 & -121.144 & 6.5 & LACC & $\begin{array}{l}\text { Top course of bricks broken off. Some bricks on roof. } \\
\text { Tarp over chimney. }\end{array}$ \\
\hline 18 & 40.239 & -121.144 & 6.5 & LACC & Chimney cracked, no debris. Tarp over chimney. \\
\hline 19 & 40.244 & -121.150 & 6.5 & LACC & $\begin{array}{l}\text { Outer bricks fell off the bottom of the chimney. Bricks } \\
\text { on deck below, no roof damage. }\end{array}$ \\
\hline 20 & 40.225 & -121.140 & 7 & LACC & $\begin{array}{l}\text { Chimney broken, railing on porch damaged by falling } \\
\text { bricks. }\end{array}$ \\
\hline 21 & 40.244 & -121.150 & 7 & LACC & Top course of bricks broken off chimney. \\
\hline
\end{tabular}




\begin{tabular}{|c|c|c|c|c|c|}
\hline N & Latitude & Longitude & MMI & City & Notes \\
\hline 22 & 40.227 & -121.141 & 7.5 & LACC & $\begin{array}{l}\text { Chimney collapsed above the roofline and broke the } \\
\text { porch. Bent doorframes, cracks in walls, cupboards } \\
\text { open and things fell out, paint chipped off. Stepwise } \\
\text { cracks in the foundation. }\end{array}$ \\
\hline 23 & 40.227 & -121.140 & 7 & LACC & $\begin{array}{l}\text { Upper half of stone chimney on side of cabin collapsed. } \\
\text { Rebar exposed. Pile of debris nearby. }\end{array}$ \\
\hline 24 & 40.231 & -121.142 & 7 & LACC & $\begin{array}{l}\text { Complete chimney collapse. Stones damaged roof and } \\
\text { porch. Debris left where it fell. }\end{array}$ \\
\hline 25 & 40.233 & -121.145 & 7 & LACC & $\begin{array}{l}\text { Chimney collapsed. Insulation visible. Pile of debris } \\
\text { nearby. }\end{array}$ \\
\hline 26 & 40.233 & -121.144 & 7.5 & LACC & $\begin{array}{l}\text { Chimney fell toward street, crushed porch. Several rocks } \\
\text { ( } 20-80 \mathrm{lbs} \text {.) fell into the house, puncturing the floor in } \\
\text { front of the fireplace and damaging some of the } \\
\text { houses substructure. }\end{array}$ \\
\hline 27 & 40.263 & -121.148 & 7 & LACC & $\begin{array}{l}\text { Coupling broken on plastic pipe. Lost } 50,000 \text { gallons of } \\
\text { water in } 1 / 2 \text { hour. }\end{array}$ \\
\hline 28 & 40.278 & -121.129 & 5.5 & LAP & $\begin{array}{l}\text { Of many large, empty decorative wine bottles, only one } \\
\text { fell in the restaurant. No plates or glasses broke. }\end{array}$ \\
\hline 29 & 40.275 & -121.125 & 6.5 & LAP & $\begin{array}{l}\text { Many items off shelves in aisles as well as wine room at } \\
\text { supermarket. }\end{array}$ \\
\hline 30 & 40.308 & -121.231 & 6 & Chester & At diner, large objects fell off of shelves. \\
\hline 31 & 40.310 & -121.229 & 5.5 & Chester & One bottle fell at the liquor store. \\
\hline 32 & 40.298 & -121.230 & 6 & Chester & $\begin{array}{l}\text { Shaking, things fell out of cupboards in apartment } \\
\text { building. }\end{array}$ \\
\hline 33 & 40.308 & -121.227 & 5.5 & Chester & $\begin{array}{l}\text { Beer bottle fell, TV shook, phone poles shaking outside, } \\
\text { people ran outside. }\end{array}$ \\
\hline 34 & 40.311 & -121.228 & 6 & Chester & Top course of bricks broken on chimney at a church. \\
\hline 35 & 40.301 & -121.006 & 6 & Westwood & $\begin{array}{l}\text { DVDs fell. Chimney broken. Nearby house had fish } \\
\text { tank splash water out. }\end{array}$ \\
\hline 36 & 40.234 & -121.196 & 6 & LAW & Small things fell off shelves. \\
\hline 37 & 40.246 & -121.216 & 6 & LAW & Things fell off shelves. \\
\hline 38 & 40.239 & -121.201 & 6 & LAW & Things fell, some dry wall cracking. \\
\hline 39 & 40.252 & -121.218 & 6.5 & LAW & $\begin{array}{l}\text { Fireplace separated from wall } 6 \text { inches, taxidermy } \\
\text { caribou head fell from fireplace, sheet rock separated, } \\
\text { some plaster cracking around kitchen. }\end{array}$ \\
\hline 40 & 40.252 & -121.219 & 7.5 & LAW & $\begin{array}{l}\text { Rocking felt in parked car in driveway. Cracks in } \\
\text { foundation and entry walkway ( } 3 \text { meters), separation } \\
\text { of walkway from house, cracks in wall around } \\
\text { fireplace. Broken irrigation pipe in basement caused } \\
\text { flooding. Separation of railing on balcony. Bent } \\
\text { doorframes. }\end{array}$ \\
\hline 41 & 40.241 & -121.202 & 8 & LAW & $\begin{array}{l}\text { Cripple wall racked, house shook for } 10 \text { seconds before } \\
\text { settling. } 31 \text { cracks total in sheet rock from settling } \\
\text { around windows and corners. Furniture knocked over, } \\
\text { refrigerator moved, drawers opened, cracks in } \\
\text { driveway widened ( } 4 \text { meters long, } 1 \mathrm{~cm} \text { wide). } \\
\text { Freestanding fireplace shifted and flue bent. Cracks in } \\
\text { beam along roof. }\end{array}$ \\
\hline
\end{tabular}




\begin{tabular}{|c|c|c|c|c|c|}
\hline $\mathbf{N}$ & Latitude & Longitude & MMI & City & Notes \\
\hline 42 & 40.217 & -121.169 & 6.5 & Almanor & $\begin{array}{l}\text { At restaurant, lakeside liquor bottles fell upstairs and } \\
\text { seeped through to lower floor. An electrical pole } \\
\text { detached and the broiler almost detached from a gas } \\
\text { line. }\end{array}$ \\
\hline 43 & 40.227 & -121.140 & 6.5 & Almanor & $\begin{array}{l}\text { Broken bottles and many items fell off shelves at } \\
\text { general store. }\end{array}$ \\
\hline 44 & 40.216 & -121.170 & 6 & Prattville & Cafe lost 30 plates and 5-6 wine glasses due to shaking. \\
\hline 45 & 40.210 & -121.158 & 6 & Canyondam & Things fell off shelves at general store. \\
\hline 46 & 40.172 & -121.073 & 6.5 & $\begin{array}{l}\text { Canyondam } \\
\text { (Quail } \\
\text { Lodge) }\end{array}$ & $\begin{array}{l}\text { Sounded like a bomb. Lamps, speakers, and computer } \\
\text { fell in the office. Kitchen cabinets opened and dishes } \\
\text { fell. A bird aviary fell and broke outside. Slight } \\
\text { drywall cracking in one guest bathroom. Things fell at } \\
\text { neighbor's cabin that is under construction. Neighbors } \\
\text { slept at the inn. }\end{array}$ \\
\hline 47 & 40.173 & -121.073 & NA & Canyondam & $\begin{array}{l}\text { PG\&E line station attendant said there had been no } \\
\text { visible damage to the station. Mentioned rock falls } \\
\text { along Highway } 89 \text {. }\end{array}$ \\
\hline 48 & 40.170 & -121.089 & 6.5 & $\begin{array}{l}\text { Almanor } \\
\text { Dam }\end{array}$ & $\begin{array}{l}\text { 1/8-inch displacement of bent at base of a column on the } \\
\text { spillway bridge. Information from EERI June } 2013 \\
\text { newsletter. }\end{array}$ \\
\hline 49 & 40.174 & -121.143 & 7 & $\begin{array}{l}\text { Butt Valley } \\
\text { Dam }\end{array}$ & $\begin{array}{l}\text { PGA }=30 \% \text { g. Possible right lateral offset of guardrail } \\
\text { bolts on crest of dam. No apparent damage to spillway } \\
\text { or dam. }\end{array}$ \\
\hline 50 & 40.115 & -121.145 & 6 & Greenville & Things fell off shelves at drug store. \\
\hline 51 & 40.139 & -120.951 & 6 & Greenville & Windows cracked and taped over at lodge. \\
\hline 52 & 40.140 & -120.950 & 6 & Greenville & Lots of things fell off shelves at supermarket. \\
\hline 53 & 40.139 & -120.945 & 5.5 & Greenville & A lamp and a glass bottle fell at hardware store. \\
\hline 54 & 40.140 & -120.950 & 5.5 & $\begin{array}{l}\text { Crescent } \\
\text { Mills }\end{array}$ & No damage, fabric and a book fell at antique store. \\
\hline 55 & 40.097 & -120.912 & 5 & Twain & Big noise, one aftershock, nothing fell at general store. \\
\hline 56 & 40.020 & -121.070 & 7.5 & Prattville & Rock $\sim 1$ cubic yard fell on CA 89 . \\
\hline 57 & 40.194 & -121.119 & 6.5 & Twain & Small slide $\sim 3$ cubic yards covered both lanes of CA 70 . \\
\hline
\end{tabular}


Table 1-2. Damage reports submitted to Plumas County Office of Emergency Services (PCOES) and MMI classifications. Comments taken verbatim from these reports.

[HB, Hamilton Branch; LACC, Lake Almanor Country Club; LAW, Lake Almanor West. The difference in the amount of detail is due to the different surveys combined in these reports. Residents submitted the more detailed reports, whereas fire fighters submitted the brief "chimney damage" reports after walking through various neighborhoods to assess damage]

\begin{tabular}{|c|c|c|c|c|c|}
\hline $\mathbf{N}$ & Latitude & Longitude & MMI & City & Comments \\
\hline 1 & 40.273 & -121.089 & 7 & HB & Chimney damage. \\
\hline 2 & 40.273 & -121.090 & 7 & $\mathrm{HB}$ & Chimney damage. \\
\hline 3 & 40.273 & -121.095 & 7.5 & $\mathrm{HB}$ & $\begin{array}{l}\text { Separated water pipe in the wall between downstairs } \\
\text { bathroom and entryway closet caused some flooding. } \\
\text { Items off shelves. Some minimal damage to the deck. }\end{array}$ \\
\hline 4 & 40.276 & -121.093 & 7 & $\mathrm{HB}$ & Chimney damage. \\
\hline 5 & 40.276 & -121.093 & 7 & $\mathrm{HB}$ & Chimney damage. \\
\hline 6 & 40.275 & -121.093 & 7 & $\mathrm{HB}$ & Chimney damage. \\
\hline 7 & 40.214 & -121.068 & 7 & $\mathrm{HB}$ & Chimney damage. \\
\hline 8 & 40.227 & -121.076 & 7 & $\mathrm{HB}$ & Chimney damage. \\
\hline 9 & 40.278 & -121.096 & 7 & $\mathrm{HB}$ & Chimney damage. \\
\hline 10 & 40.273 & -121.089 & 7 & $\mathrm{HB}$ & Chimney damage. \\
\hline 11 & 40.205 & -121.067 & 7 & $\mathrm{HB}$ & Chimney damage. \\
\hline 12 & 40.272 & -121.094 & 7 & $\mathrm{HB}$ & Chimney damage. \\
\hline 13 & 40.278 & -121.109 & 7.5 & $\mathrm{HB}$ & Foundation twisted, chimney damage. \\
\hline 14 & 40.227 & -121.141 & 6 & LACC & Fence damage. \\
\hline 15 & 40.250 & -121.150 & 7 & LACC & $\begin{array}{l}\text { Structural damage to chimney. Slate facing fell from } \\
\text { fireplace. Drywall damage. Impact damage to hardwood } \\
\text { floors. }\end{array}$ \\
\hline 16 & 40.250 & -121.151 & 7 & LACC & Chimney damage. \\
\hline 17 & 40.251 & -121.150 & 7 & LACC & Chimney damage. \\
\hline 18 & 40.253 & -121.145 & 7 & LACC & $\begin{array}{l}\text { The rock wall behind the wood stove was cracked and was } \\
\text { separating from the wall. }\end{array}$ \\
\hline 19 & 40.251 & -121.146 & 7 & LACC & Chimney damage. \\
\hline 20 & 40.256 & -121.152 & 7 & LACC & Chimney damage. \\
\hline 21 & 40.253 & -121.146 & 7 & LACC & Chimney damage. \\
\hline 22 & 40.255 & -121.149 & 7 & LACC & Chimney damage. \\
\hline 23 & 40.262 & -121.132 & 7 & LACC & $\begin{array}{l}\text { Chimney damage and foundation cracking at Fire Station } \\
\text { surveyed by Curt Haselton (California State University). }\end{array}$ \\
\hline 24 & 40.263 & -121.131 & 7 & LACC & Chimney damage. \\
\hline 25 & 40.262 & -121.134 & 7.5 & LACC & Cracked foundation, plumbing damage. \\
\hline 26 & 40.270 & -121.128 & 7 & LACC & Chimney damage. \\
\hline 27 & 40.230 & -121.076 & 7 & LACC & Chimney damage. \\
\hline 28 & 40.214 & -121.067 & 7 & LACC & Chimney damage. \\
\hline
\end{tabular}




\begin{tabular}{|c|c|c|c|c|c|}
\hline N & Latitude & Longitude & MMI & City & Comments \\
\hline 29 & 40.275 & -121.125 & 7 & LACC & Chimney damage. \\
\hline 30 & 40.228 & -121.141 & 7 & LACC & Chimney damage. \\
\hline 31 & 40.233 & -121.145 & 7 & LACC & Foundation damage. \\
\hline 32 & 40.233 & -121.142 & 7 & LACC & Chimney damage. \\
\hline 33 & 40.236 & -121.147 & 7 & LACC & Chimney damage. \\
\hline 34 & 40.238 & -121.147 & 7 & LACC & Chimney damage. \\
\hline 35 & 40.239 & -121.144 & 7 & LACC & Chimney damage. \\
\hline 36 & 40.240 & -121.147 & 7 & LACC & $\begin{array}{l}\text { Fireplace chimney damage. TV broken. Crack in wall. Items } \\
\text { off shelves. }\end{array}$ \\
\hline 37 & 40.239 & -121.144 & 7 & LACC & Chimney damage. \\
\hline 38 & 40.241 & -121.146 & 7.5 & LACC & $\begin{array}{l}\text { Walls cracked, all possessions destroyed. Everything in } \\
\text { house on the ground. }\end{array}$ \\
\hline 39 & 40.242 & -121.147 & 7 & LACC & Chimney damage. \\
\hline 40 & 40.244 & -121.145 & 7 & LACC & Chimney damage. \\
\hline 41 & 40.245 & -121.145 & 7 & LACC & Chimney damage. \\
\hline 42 & 40.255 & -121.146 & 7 & LACC & 8 feet off top of block damaged. Needs flue line and cap. \\
\hline 43 & 40.231 & -121.143 & 7 & LACC & Chimney collapse. \\
\hline 44 & 40.270 & -121.143 & 7 & LACC & Chimney collapse. \\
\hline 45 & 40.243 & -121.216 & 7 & LAW & Chimney, floors, cracked beams. \\
\hline 46 & 40.248 & -121.145 & 7 & LACC & Chimney and roof damage. \\
\hline 47 & 40.227 & -121.140 & 7 & LACC & Chimney, deck. \\
\hline 48 & 40.227 & -121.140 & 7.5 & LACC & Chimney collapse, broken windows, deck. \\
\hline 49 & 40.227 & -121.140 & 7 & LACC & $\begin{array}{l}\text { Exterior chimney completely collapsed off the side of the } \\
\text { cabin. }\end{array}$ \\
\hline 50 & 40.229 & -121.142 & 7.5 & LACC & $\begin{array}{l}\text { Chimney collapsed. Front façade (adobe bricks) of fireplace } \\
\text { fell into the living room. Large piece of chimney broke } \\
\text { through a piece of redwood deck. Front porch pulled away } \\
\text { and loosened. Items off shelves and walls. }\end{array}$ \\
\hline 51 & 40.235 & -121.200 & 7 & LAW & Broken water line in house. \\
\hline 52 & 40.236 & -121.211 & 7 & LAW & Broken water line in house. \\
\hline 53 & 40.235 & -121.202 & 7 & LAW & Broken water line in house. \\
\hline 54 & 40.236 & -121.201 & 7.5 & LAW & $\begin{array}{l}\text { Stone light pillars tilted, driveway pavers lifted, thrown, } \\
\text { sunken and cracked. Concrete edges of driveway cracked. } \\
\text { Water service line broken. Hot water heater and supply } \\
\text { valve leaking. } 1 / 3 \text { of kitchen contents destroyed. Antique } \\
\text { glass collection mostly destroyed. Significant surface } \\
\text { damage to interior sheetrock in garages and first floor of } \\
\text { house. Minor damage to furniture. Wood stoves shifted } \\
\text { resulting in chimney pipes becoming disconnected. } \\
\text { Exterior chimney siding fell and (or) displaced, wood deck } \\
\text { damaged. }\end{array}$ \\
\hline
\end{tabular}




\begin{tabular}{|c|c|c|c|c|c|}
\hline N & Latitude & Longitude & MMI & City & Comments \\
\hline 55 & 40.236 & -121.203 & 7.5 & LAW & $\begin{array}{l}\text { Structural damage to foundation under one exterior wall and } \\
\text { one interior wall. Numerous violations of drywall in form } \\
\text { of tape and texture repair necessary. Damage to kitchen } \\
\text { and bathroom tiles, hearth. }\end{array}$ \\
\hline 56 & 40.241 & -121.199 & 7 & LAW & $\begin{array}{l}\text { Major cracked and chunked drywall in all rooms. Torn } \\
\text { wallpaper. Some tile damage. A new oven top was cracked } \\
\text { and light fixtures fell and broke. }\end{array}$ \\
\hline 57 & 40.243 & -121.213 & 7 & LAW & Partial chimney collapse. \\
\hline 58 & 40.250 & -121.218 & 8 & LAW & Rock wall collapsed, floor damage, broken floor joist. \\
\hline 59 & 40.249 & -121.219 & 7 & LAW & Partial chimney collapse. \\
\hline 60 & 40.240 & -121.210 & 7.5 & LAW & $\begin{array}{l}\text { Cracked walls throughout house. Damaged household } \\
\text { glassware and mirrors. Cracked concrete, broken asphalt, } \\
\text { septic line (house to tank) sunk, broken block retaining } \\
\text { wall. }\end{array}$ \\
\hline 61 & 40.242 & -121.212 & 8 & LAW & $\begin{array}{l}\text { Damage to 3rd and 2nd floor balconies. Support beams } \\
\text { damaged, doorframes shifted, water heater moved, furnace } \\
\text { now filling house with smoke. Drywall damage. Large } \\
\text { cracks in cement around house and into garage. Driveway } \\
\text { has sunk, too. }\end{array}$ \\
\hline 62 & 40.249 & -121.218 & 8 & LAW & House shifted on foundation. \\
\hline 63 & 40.215 & -121.171 & 7 & Almanor & $\begin{array}{l}\text { Glass electric cooktop damaged. Kitchen cabinets separated } \\
\text { from ceiling. }\end{array}$ \\
\hline 64 & 40.141 & -120.958 & 7 & Greenville & $\begin{array}{l}\text { The fireplace is sinking, separating from the house (cracks in } \\
\text { masonry work inside and outside). An outbuilding } \\
\text { collapsed. }\end{array}$ \\
\hline
\end{tabular}


Table 1-3. DYFI reports and assigned CDIs from nearby ZIP Codes. Comments from respondents edited to contain only damage and felt information.

[HB, Hamilton Branch; LACC, Lake Almanor Country Club; LAP, Lake Almanor Peninsula; LAW, Lake Almanor West. CDIs in parentheses indicate the report was not used because the assigned CDI does not correspond with the respondent's comments]

\begin{tabular}{|c|c|c|c|c|c|}
\hline $\mathbf{N}$ & Latitude & Longitude & CDI & City & Comments \\
\hline 1 & 40.277 & -121.105 & 5.8 & $\mathrm{HB}$ & $\begin{array}{l}\text { Thought for a few moments that the house was } \\
\text { going to fall over! }\end{array}$ \\
\hline 2 & 40.278 & -121.098 & 7.7 & $\mathrm{HB}$ & \\
\hline 3 & 40.235 & -121.144 & 5.6 & LACC & \\
\hline 4 & 40.244 & -121.151 & 6.8 & LACC & $\begin{array}{l}\text { First very sharp jolt, then about } 1.5 \text { or maybe } 2 \\
\text { seconds, then numerous very sharp violent jolts, } \\
\text { about } 1 \text { second period. Like the Jolly Green Giant } \\
\text { was punching the house as hard as he could. }\end{array}$ \\
\hline 5 & 40.245 & -121.143 & 5.3 & LACC & \\
\hline 6 & 40.255 & -121.147 & 5.8 & LACC & $\begin{array}{l}\text { Many drawers opened. Broken glass and pottery. } \\
\text { Deer head mount fell off wall and broken antlers. }\end{array}$ \\
\hline 7 & 40.272 & -121.131 & 5.3 & LAP & Strongest shake I've ever experienced. \\
\hline 8 & 40.275 & -121.129 & 2.7 & LAP & \\
\hline 9 & 40.278 & -121.119 & 5.6 & LAP & \\
\hline 10 & 40.290 & -121.139 & 4.8 & LAP & \\
\hline 11 & 40.295 & -121.135 & 5.9 & LAP & \\
\hline 12 & 40.283 & -121.143 & 6.5 & LAP & $\begin{array}{l}\text { Trees were swaying } \pm 3 \text { feet, difficult to stand up } \\
\text { and several items toppled off the fireplace mantle. }\end{array}$ \\
\hline 13 & 40.305 & -121.223 & 6.0 & Chester & $\begin{array}{l}\text { Was sitting on a couch, and suddenly felt a strong } \\
\text { tremor. }\end{array}$ \\
\hline 14 & 40.306 & -121.227 & 6.1 & Chester & \\
\hline 15 & 40.309 & -121.224 & $(2.0)$ & Chester & $\begin{array}{l}\text { Nothing on shelves moved or fell. I was holding the } \\
\text { TV to ensure it didn't move/fall. The entire apt } \\
\text { moved back and forth (walls visibly swayed 1-2 } \\
\text { feet), yet nothing fell off walls or shelves. }\end{array}$ \\
\hline 16 & 40.298 & -121.006 & $(2.0)$ & Westwood & Splashed water from 50-gallon aquarium. \\
\hline 17 & 40.301 & -121.006 & 6.1 & Westwood & $\begin{array}{l}\text { I almost fell over from the jolt. Power lines and } \\
\text { trees were shaking/swaying above us. CDs, books } \\
\text { fell off the shelves and the bathroom cabinets } \\
\text { were open and our items fell out on the floor. }\end{array}$ \\
\hline 18 & 40.302 & -121.007 & 4.7 & Westwood & \\
\hline 19 & 40.308 & -121.002 & 4.6 & Westwood & \\
\hline 20 & 40.308 & -121.006 & 5.6 & Westwood & \\
\hline 21 & 40.311 & -121.002 & 3.8 & Westwood & Felt like a 4.0. \\
\hline 22 & 40.313 & -120.994 & 5.8 & Westwood & \\
\hline 23 & 40.295 & -121.050 & 4.5 & Clear Creek & \\
\hline 24 & 40.239 & -121.201 & 6.1 & LAW & \\
\hline 25 & 40.235 & -121.206 & 7.0 & LAW & \\
\hline 26 & 40.235 & -121.194 & 7.5 & LAW & $\begin{array}{l}\text { Very abrupt onset, with strong north-to-south } \\
\text { movement. }\end{array}$ \\
\hline 27 & 40.241 & -121.201 & 7.4 & LAW & $\begin{array}{l}\text { My wood stove shifted several inches. I have a lot } \\
\text { of broken glass from objects falling from cabinet, } \\
\text { pictures, and light bulbs. }\end{array}$ \\
\hline 28 & 40.241 & -121.202 & 7.5 & LAW & $\begin{array}{l}\text { Glad the shaking didn't last any longer, as the } \\
\text { damage would have been much worse. }\end{array}$ \\
\hline
\end{tabular}




\begin{tabular}{rrrrll}
\hline $\mathbf{N}$ & Latitude & Longitude & CDI & \multicolumn{1}{c}{ City } & Comments \\
\hline 29 & 40.244 & -121.213 & 7.3 & LAW & \\
\hline 30 & 40.252 & -121.219 & 7.0 & LAW & \\
\hline 31 & 40.198 & -121.136 & 6.1 & Canyondam & \\
\hline 32 & 40.126 & -120.821 & 4.6 & Greenville & \\
\hline 33 & 40.135 & -120.949 & 6.7 & Greenville & \\
\hline 34 & 40.137 & -120.867 & 4.8 & Greenville &
\end{tabular}

Felt strong shaking for 30 to 40 seconds. 1/4-1/3 inch separation of walls in two locations from adjacent post, ceiling and (or) wall. A cabinet moved violently enough to chip the wall on one corner.

\begin{tabular}{llllll}
\hline 36 & 40.138 & -120.953 & 5.6 & Greenville & \\
\hline 37 & 40.140 & -120.951 & 5.4 & Greenville & $\begin{array}{c}\text { Less "shaking" and more like strong ongoing } \\
\text { rocking. }\end{array}$ \\
\hline 38 & 40.140 & -120.947 & 6.7 & Greenville & \\
\hline 39 & 40.141 & -120.947 & 5.6 & Greenville & \\
\hline 40 & 40.144 & -120.902 & 4.1 & Greenville & \\
\hline 41 & 40.146 & -120.916 & 5.8 & Greenville & \\
\hline 42 & 40.149 & -120.956 & 6.0 & Greenville & \\
\hline 43 & 40.150 & -120.940 & 5.6 & Greenville & \\
\hline 44 & 40.151 & -120.937 & 6.1 & Greenville & $\begin{array}{c}\text { I live in a doublewide mobile home. The walls } \\
\text { shook and the boards cracked. }\end{array}$ \\
\hline 45 & 40.160 & -120.939 & 5.3 & Greenville & \\
\hline 46 & 40.166 & -120.960 & 5.6 & Greenville & \\
\hline 47 & 40.169 & -120.791 & 5.3 & Greenville & Whole house shook in an east-to-west motion. \\
\hline 48 & 40.106 & -120.909 & 3.1 & Crescent Mills & \\
\hline 49 & 40.036 & -121.131 & 6.5 & Twain & \\
\hline 50 & 40.053 & -121.137 & 6.8 & Twain & \\
\hline
\end{tabular}




\section{Appendix 2. Damage Photographs}

Site enumerations refer to the entries in table 1-1; for example, site 1.1.5 corresponds to table 1-1, item 5. HB, Hamilton Branch; LACC, Lake Almanor Country Club; LAP, Lake Almanor Peninsula; LAW, Lake Almanor West.

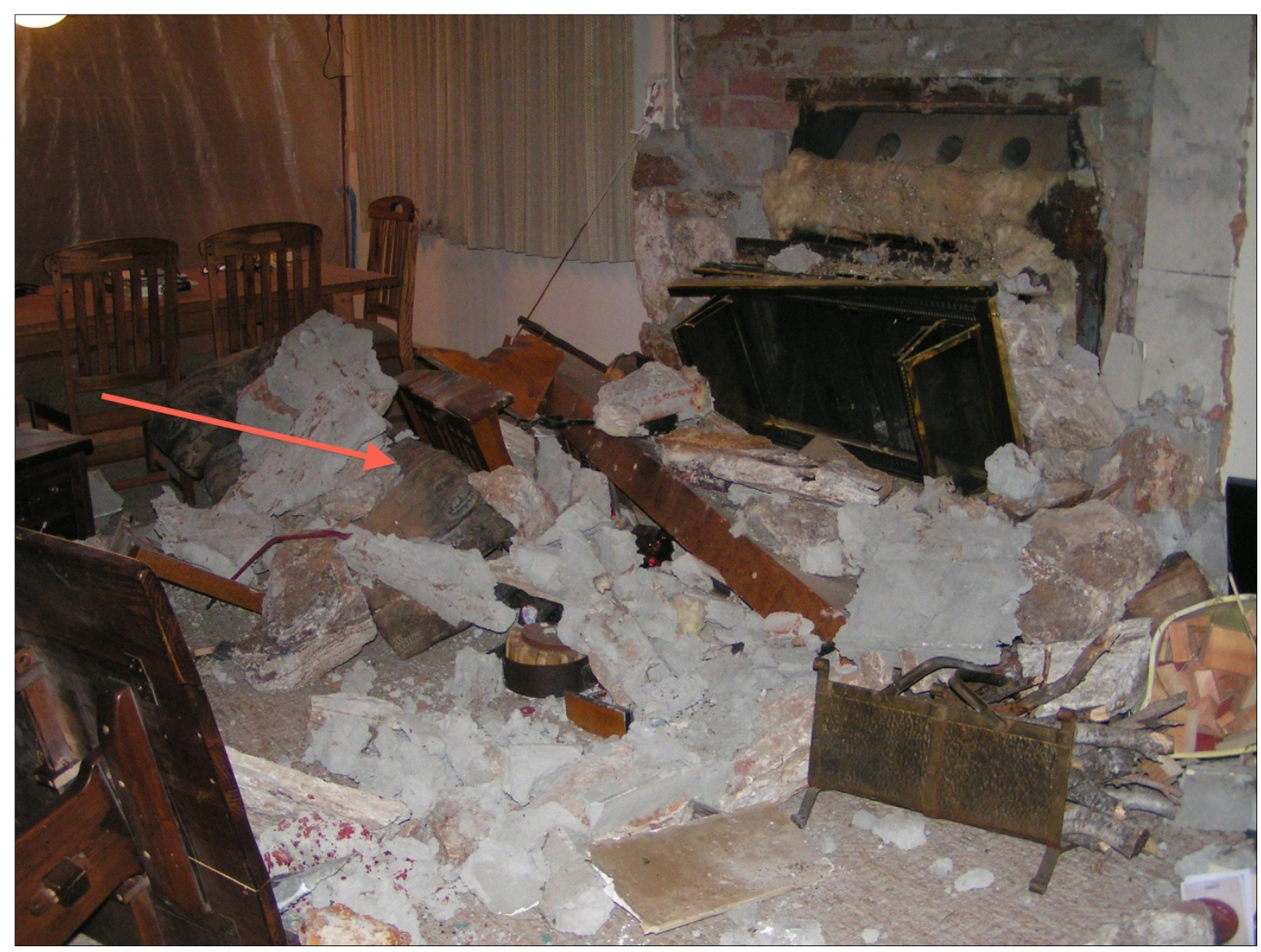

Figure 2-1. Internal damage at site 1.1.5, a house on Peninsula Drive in LACC. Brick fireplace and mantle collapsed into the home, damaging furniture and injuring one resident. Photo courtesy of homeowner. 


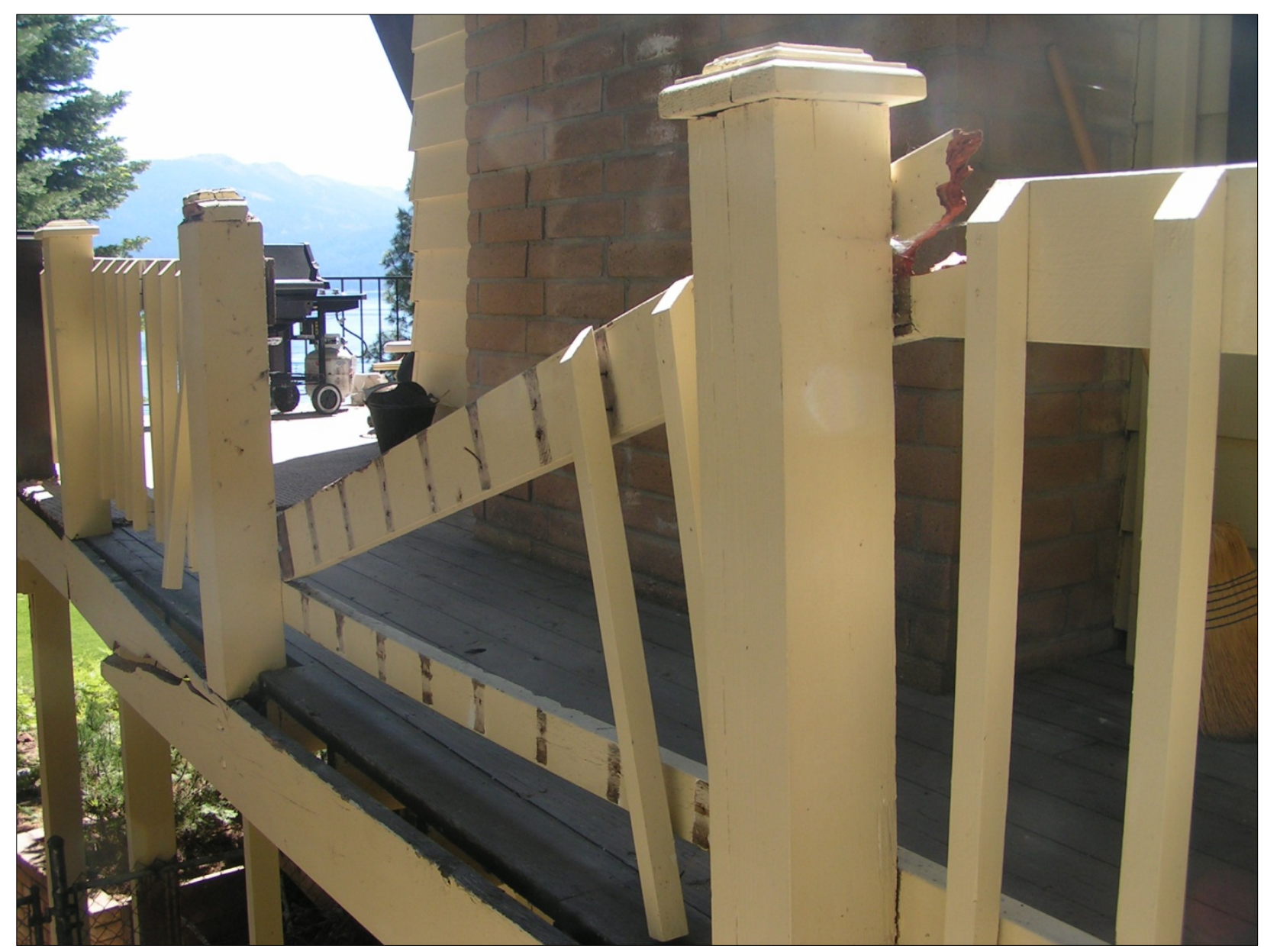

Figure 2-2. Porch railing damage to site 1.1.5 in LACC. Chimney collapsed above the roofline (in right background of photo) and damaged the porch railing as it fell. Porch became separated from the house by several inches. Photo courtesy of homeowner. 


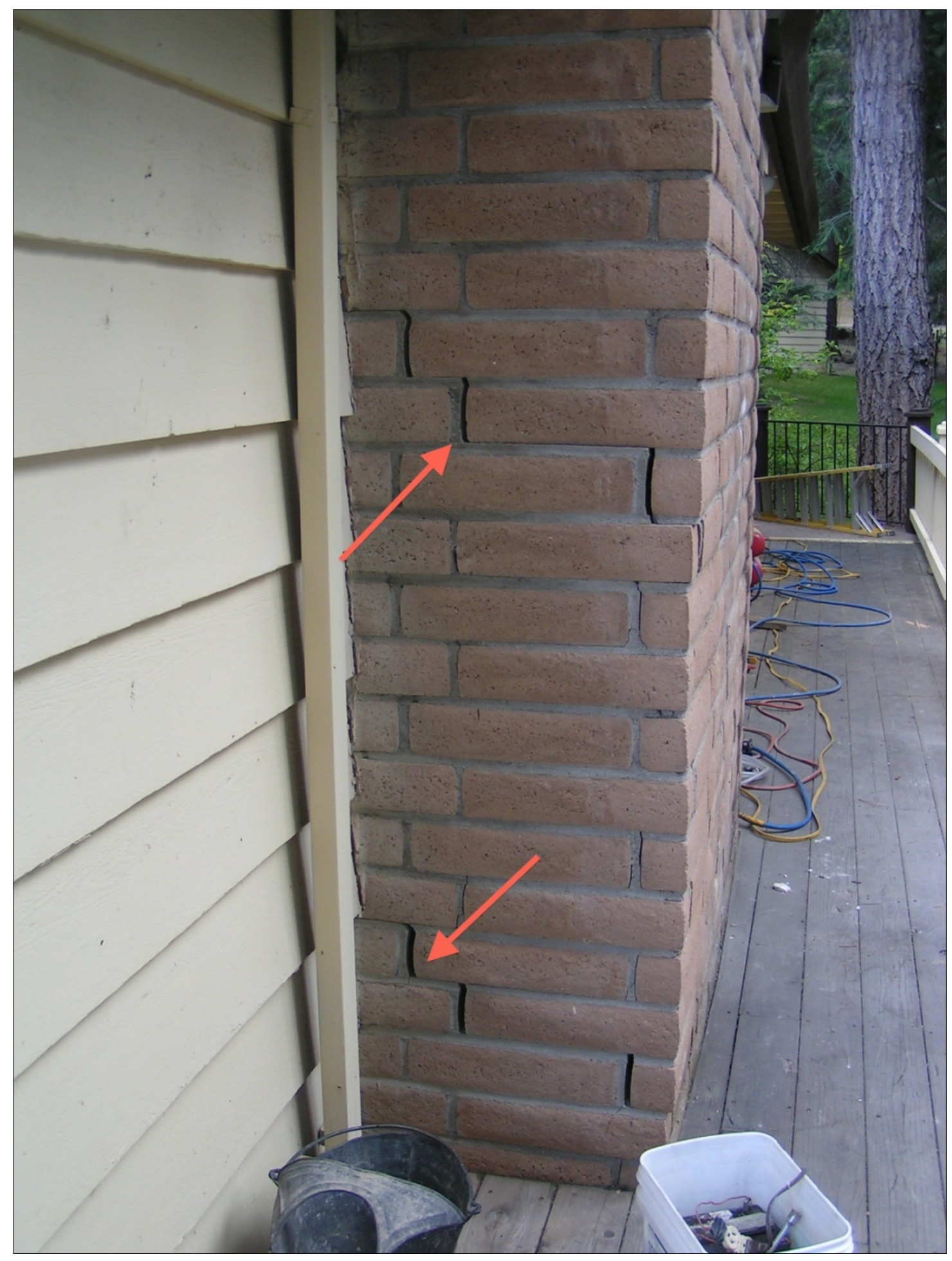

Figure 2-3. Chimney separation at site 1.1.5 in LACC. Separation of bricks in remaining chimney that collapsed above the roofline. 


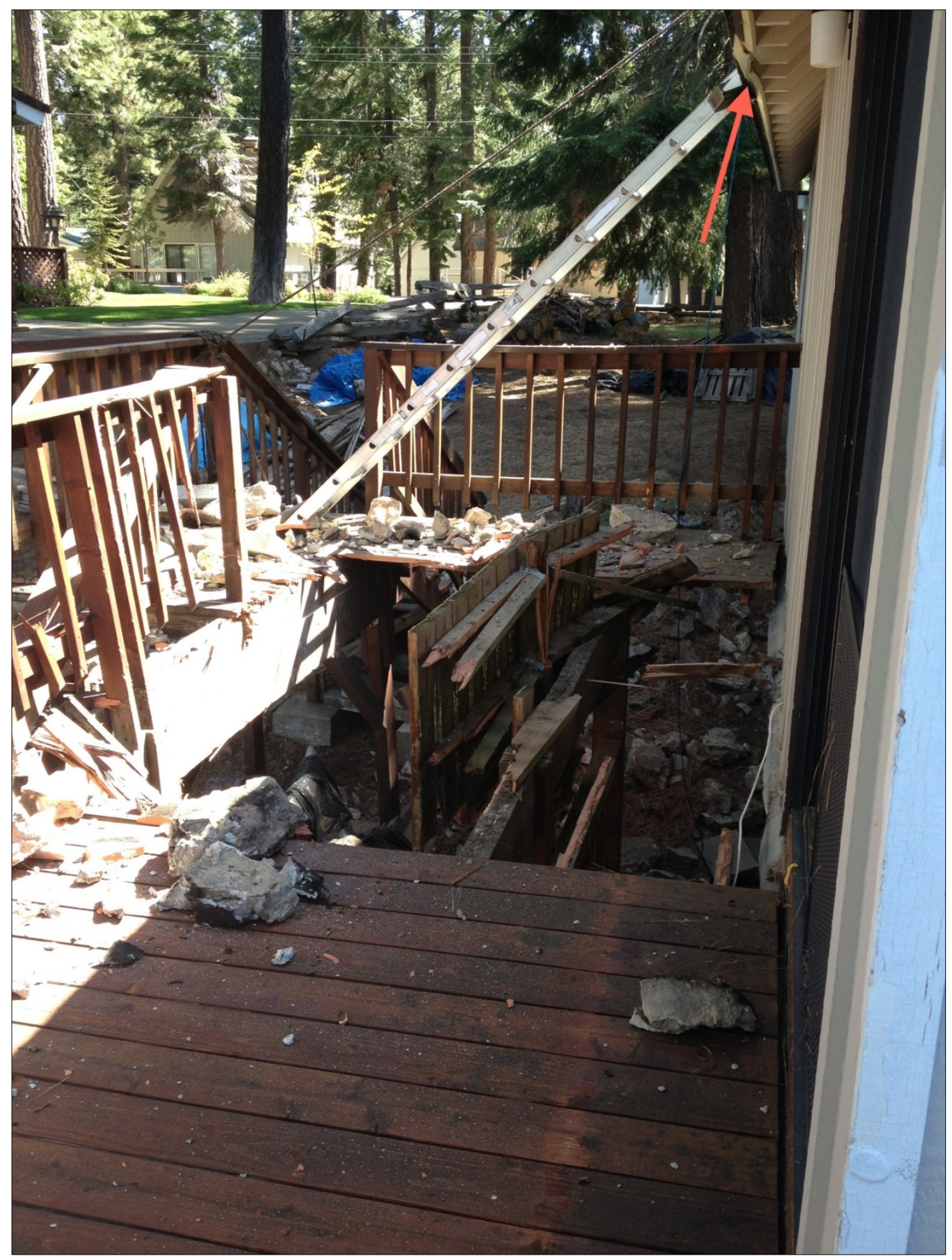

Figure 2-4. Deck damage at site 1.1.22, on Lassen View Drive in LACC. Chimney collapsed (arrow indicates approximate location) and significantly damaged porch when it fell. Photo courtesy of homeowner. 


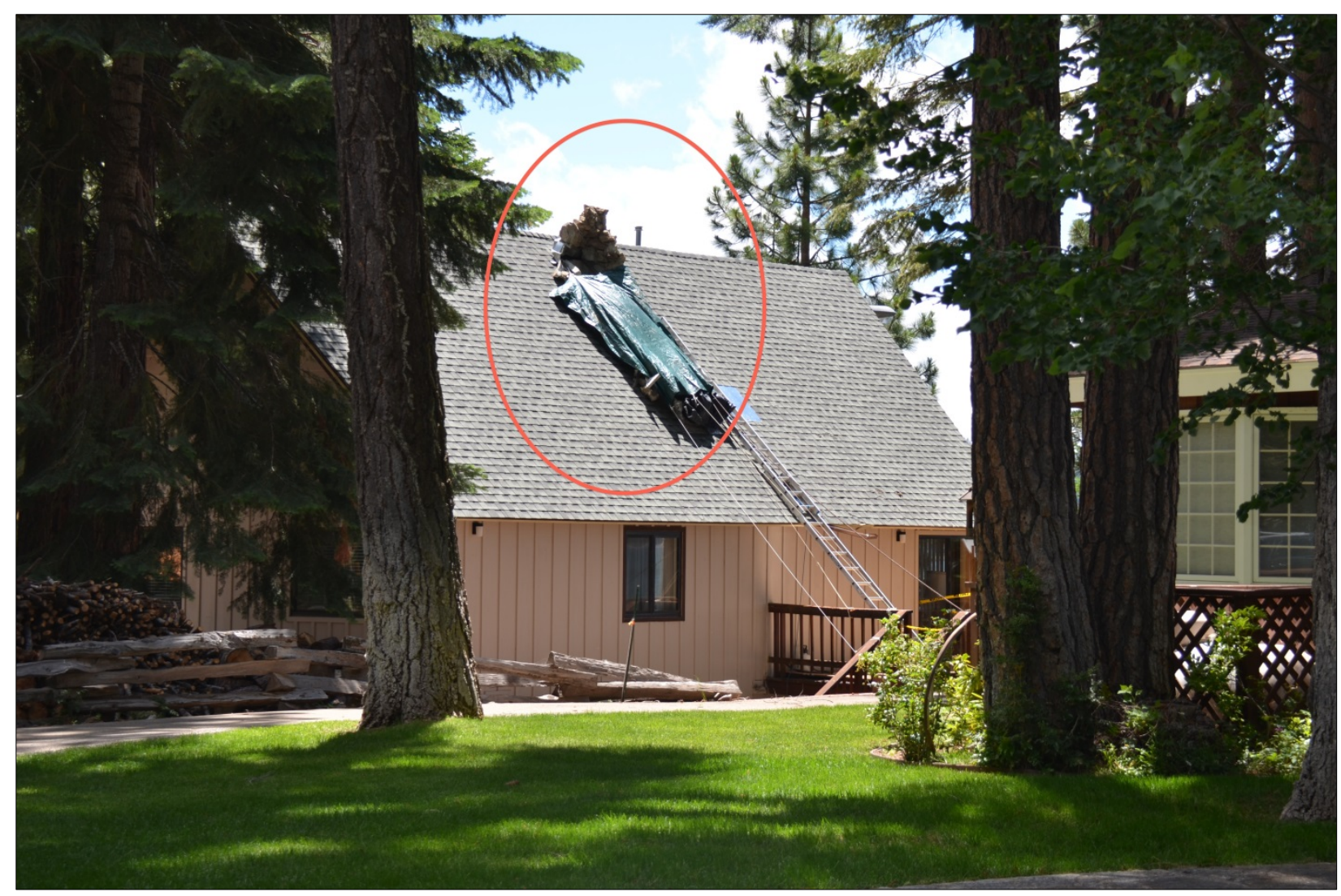

Figure 2-5. Chimney damage to site 1.1.22 in LACC. 


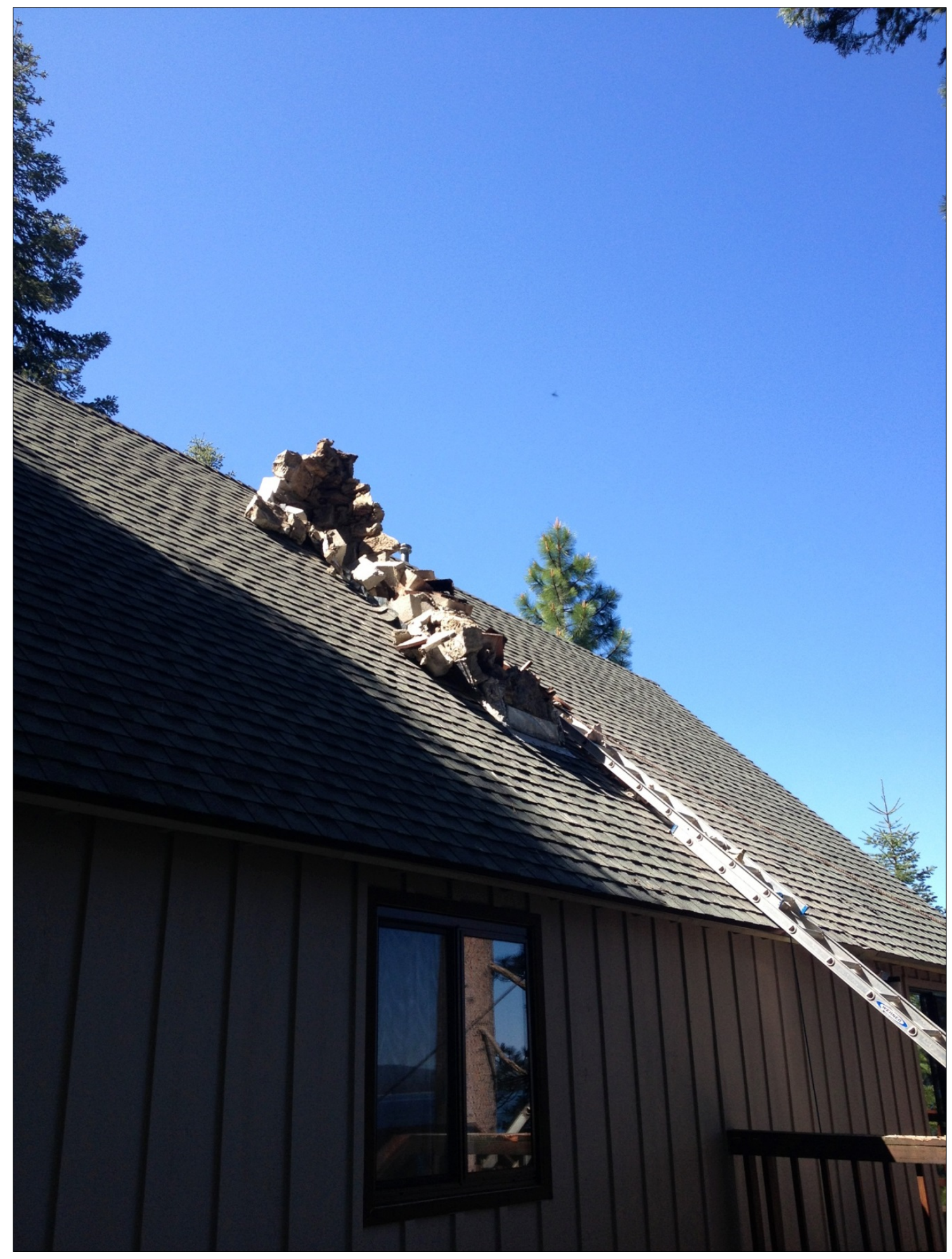

Figure 2-6. Chimney damage at site 1.1.22 in LACC. Remains of chimney immediately after collapse. Roof was damaged where the bricks fell. Photo courtesy of homeowner. 


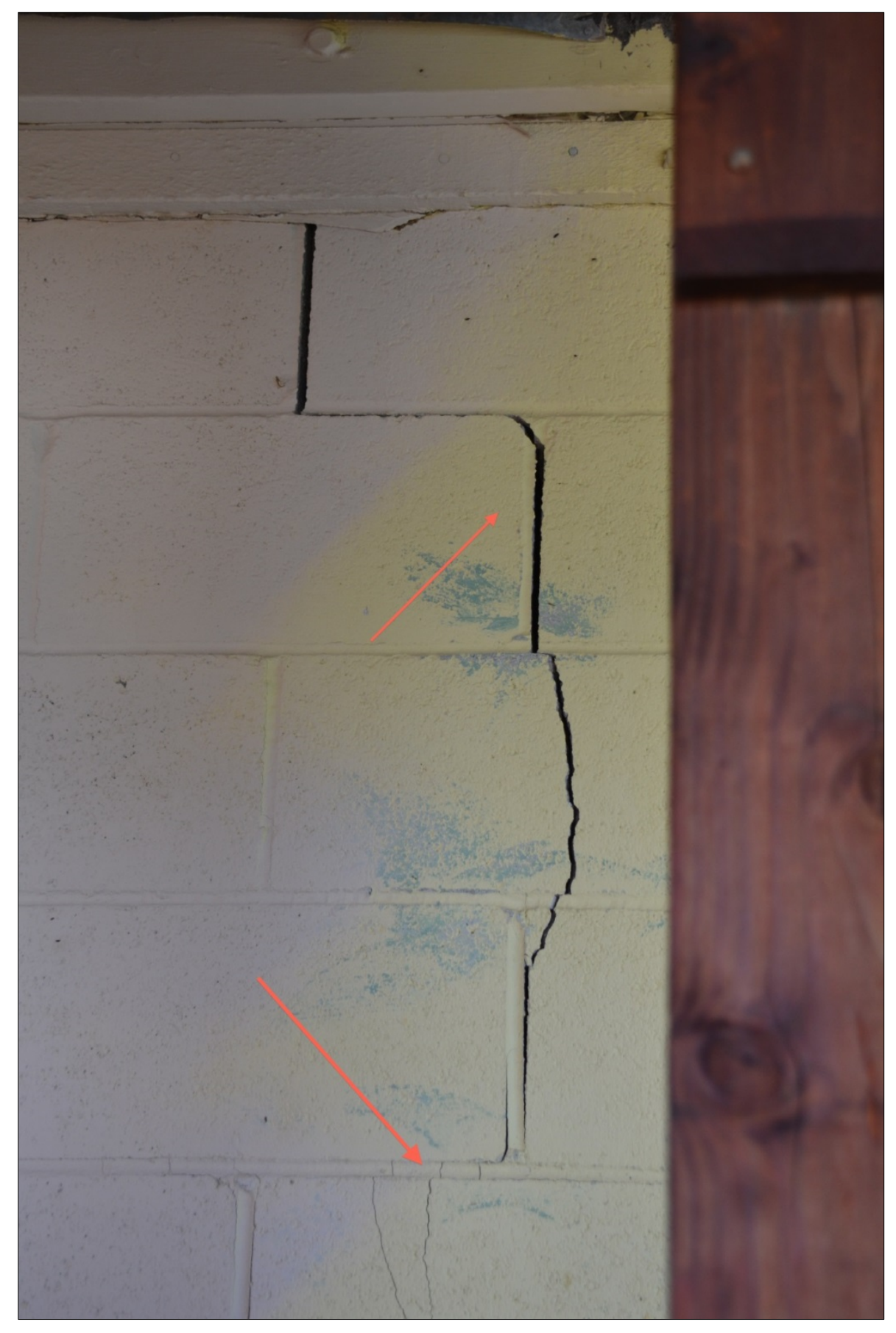

Figure 2-7. Foundation cracking at site 1.1.21 in LACC. 


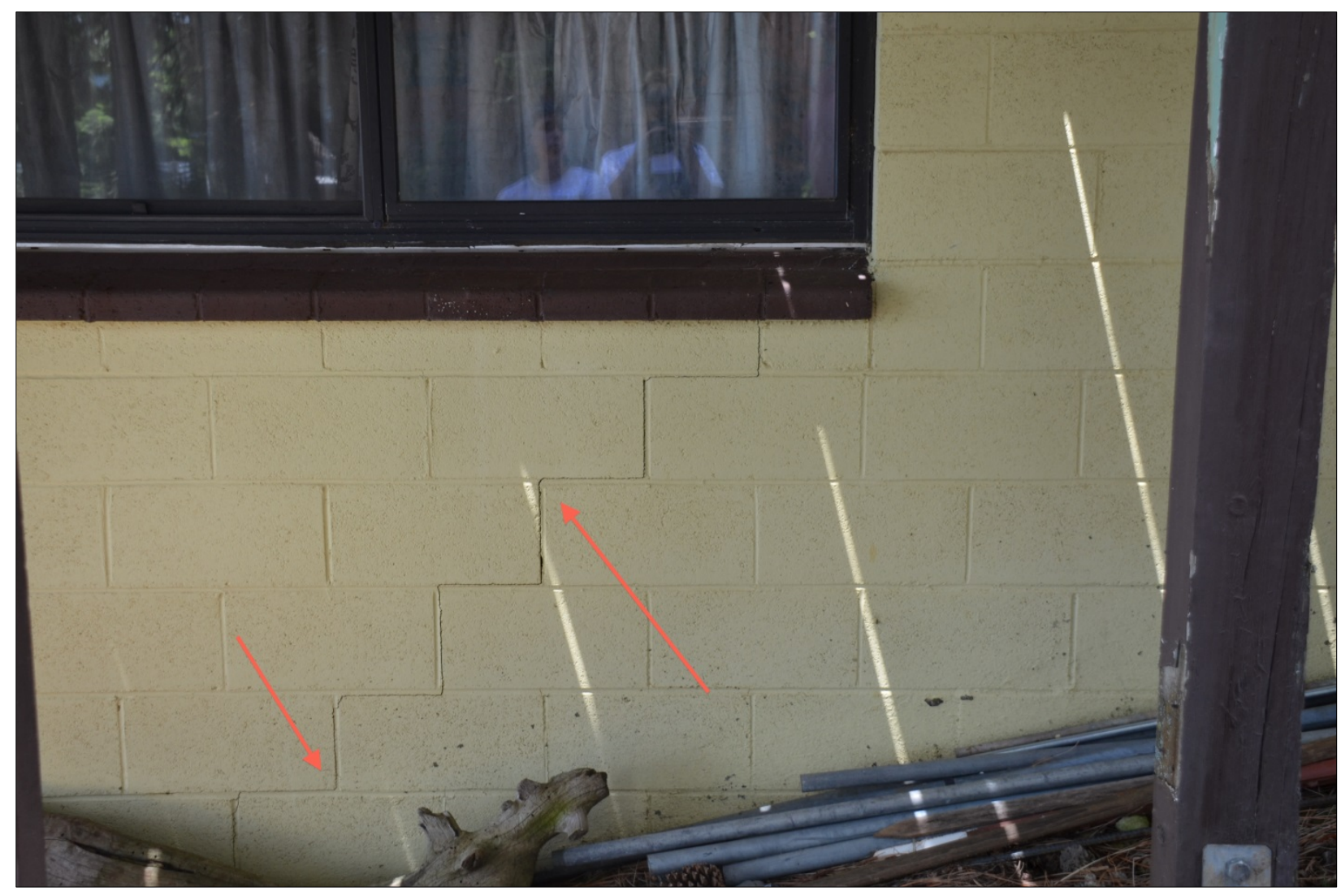

Figure 2-8. Stepwise foundation cracking at site 1.1.22 in LACC. 


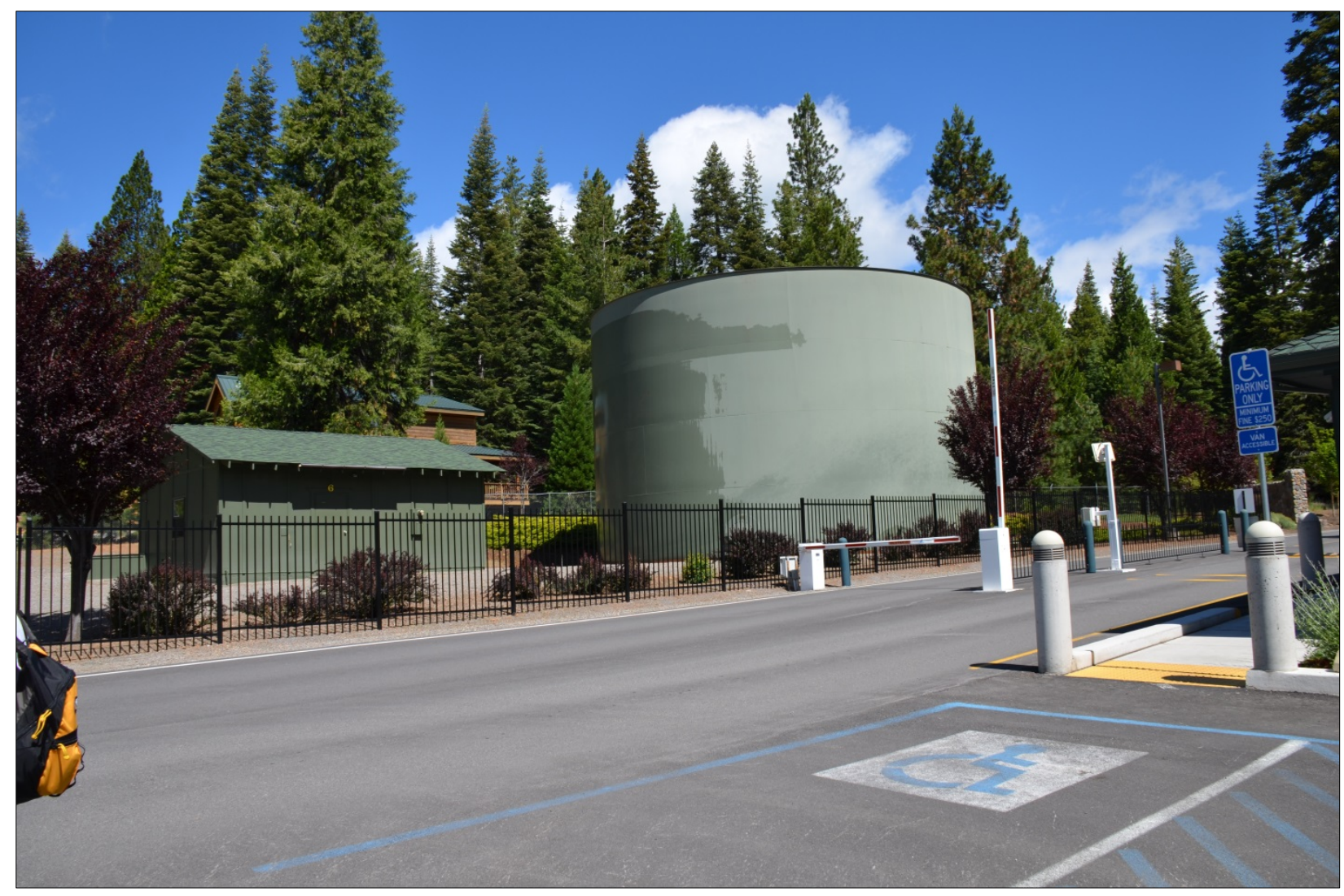

Figure 2-9. Water tank in LACC, at site 1.1.28. The earthquake caused a coupling to break, and 50,000 gallons of water were spilled before LACC Mutual Water Company shut off the leak. 


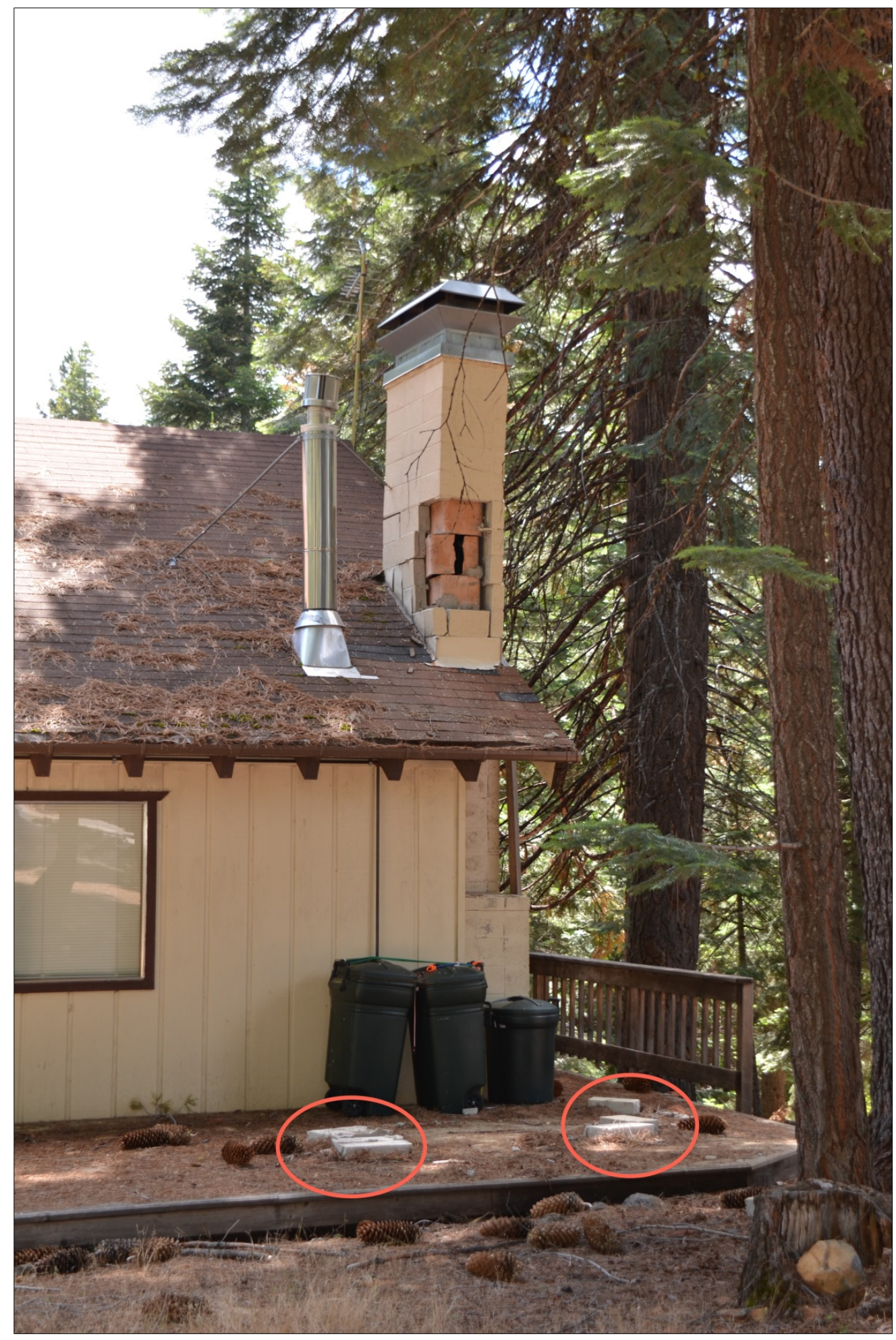

Figure 2-10. Chimney damage at site 1.1.19 in LACC. 


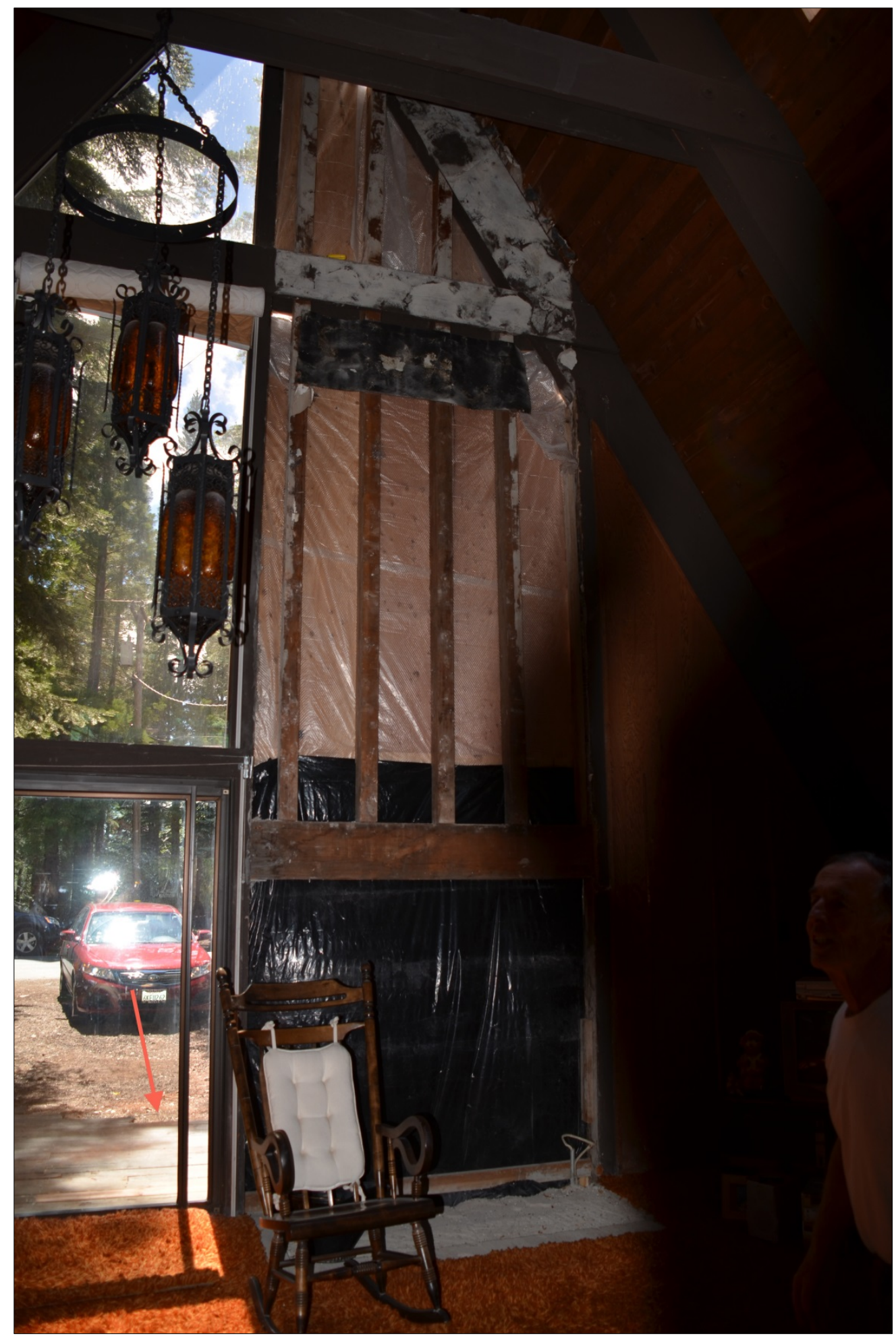

Figure 2-11. Chimney damage at site 1.1.26 in LACC. Chimney collapsed both internally and externally. Falling bricks and stones damaged deck and floor. 


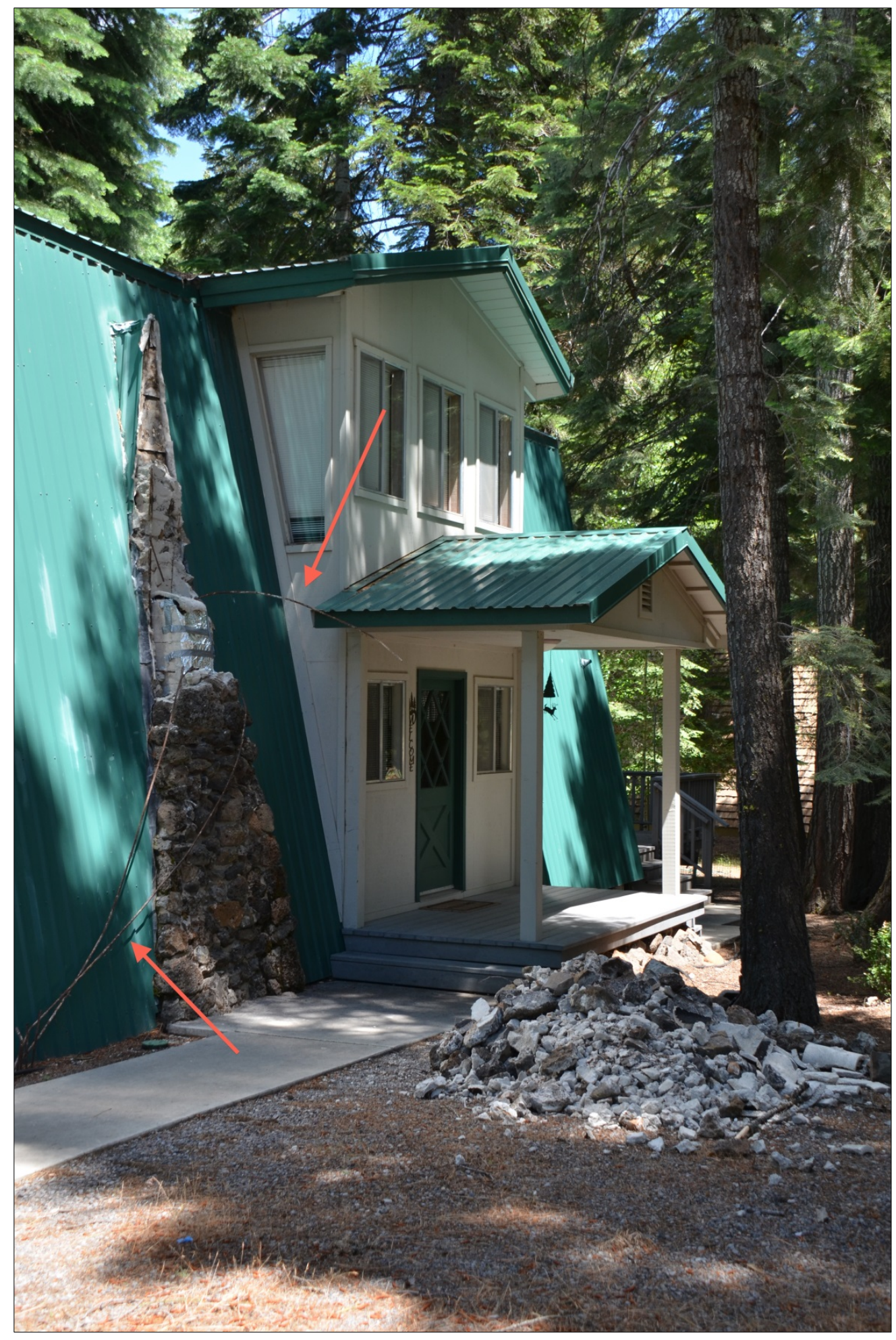

Figure 2-12. Chimney collapse at site 1.1.23 in LACC. Exposed rebar indicates the chimney was "reinforced." 


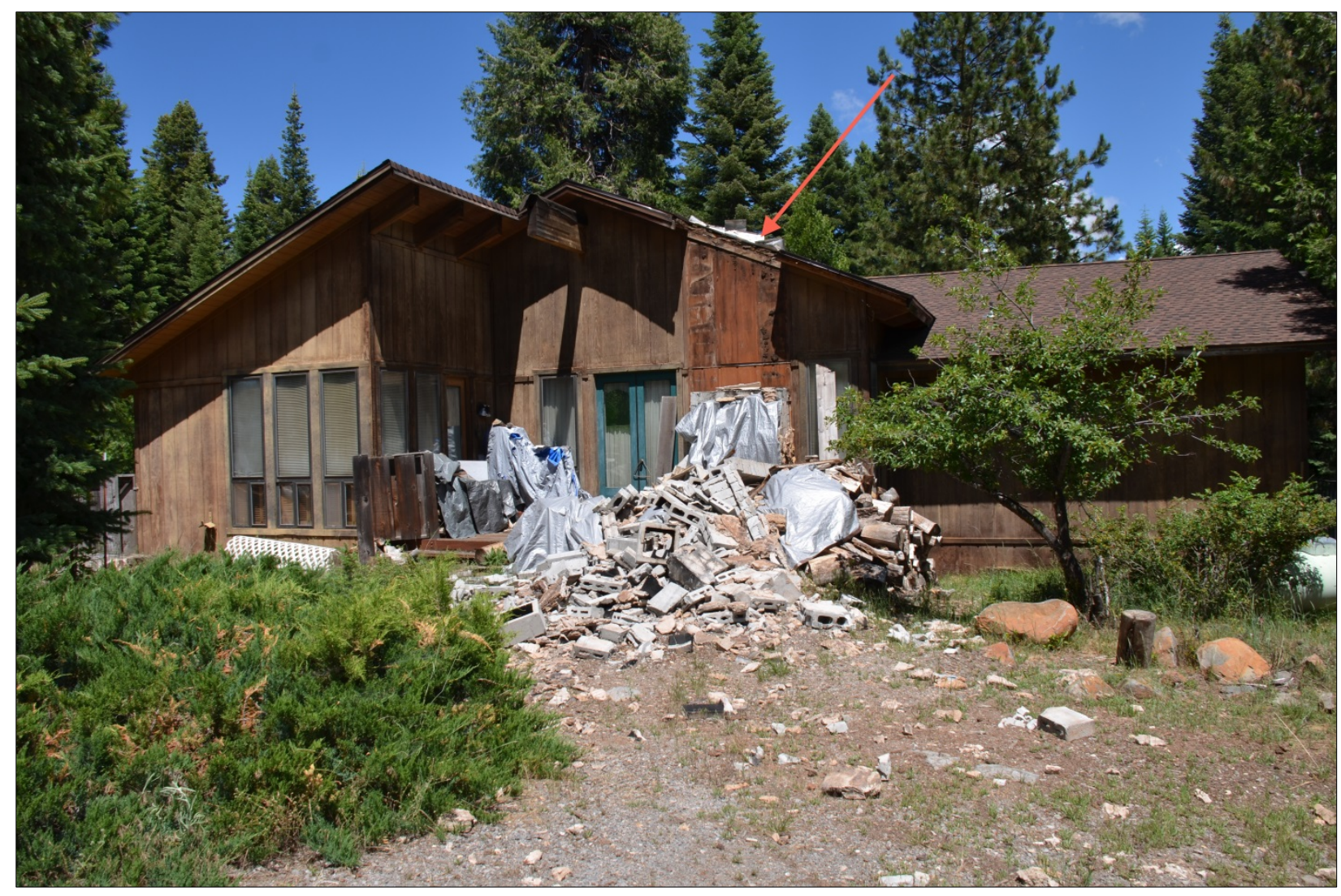

Figure 2-13. Chimney collapse at site 1.1.24 in LACC. 


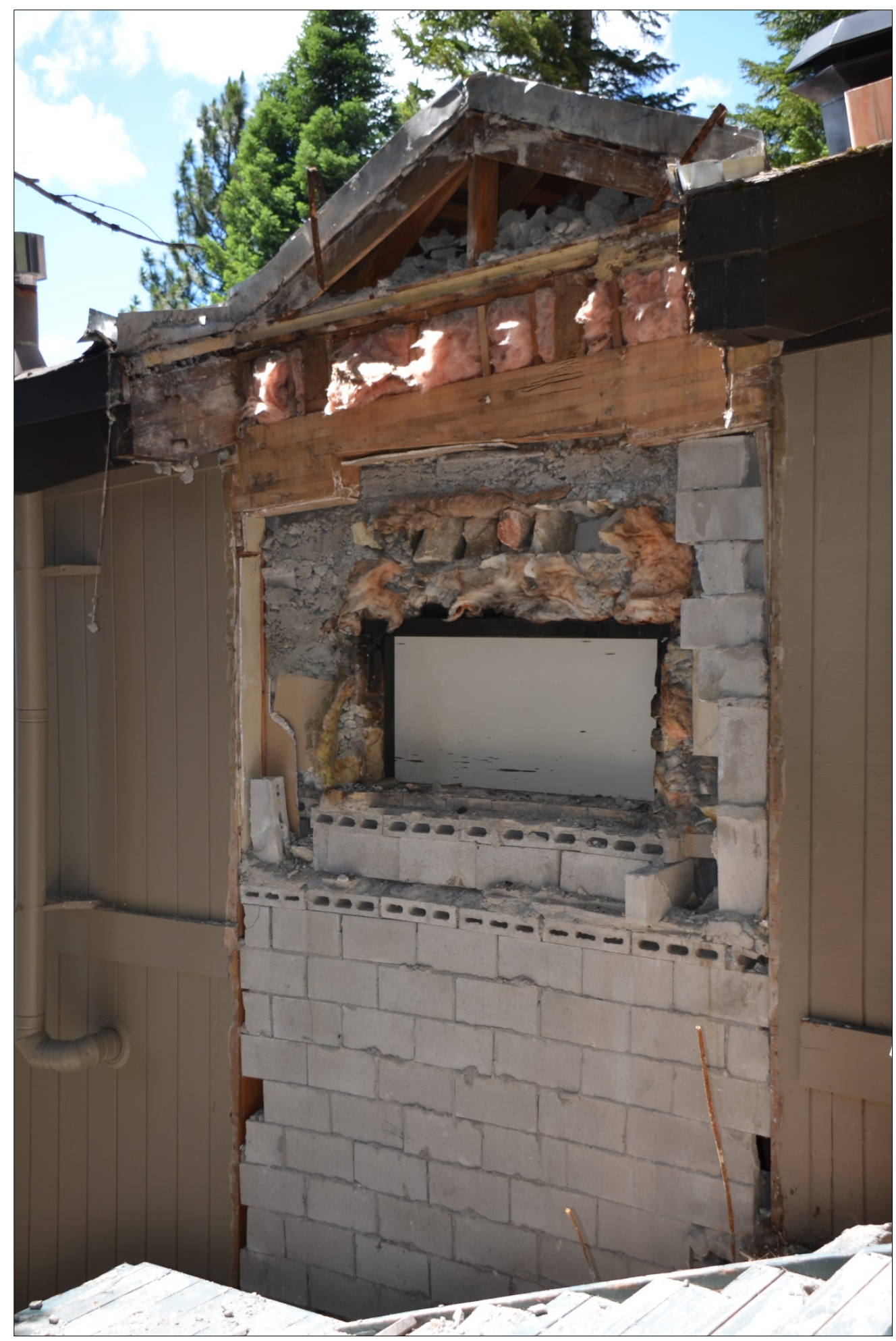

Figure 2-14. Chimney collapse at site 1.1.25 in LACC. Homeowners had cleaned up chimney pieces before the photo was taken. 


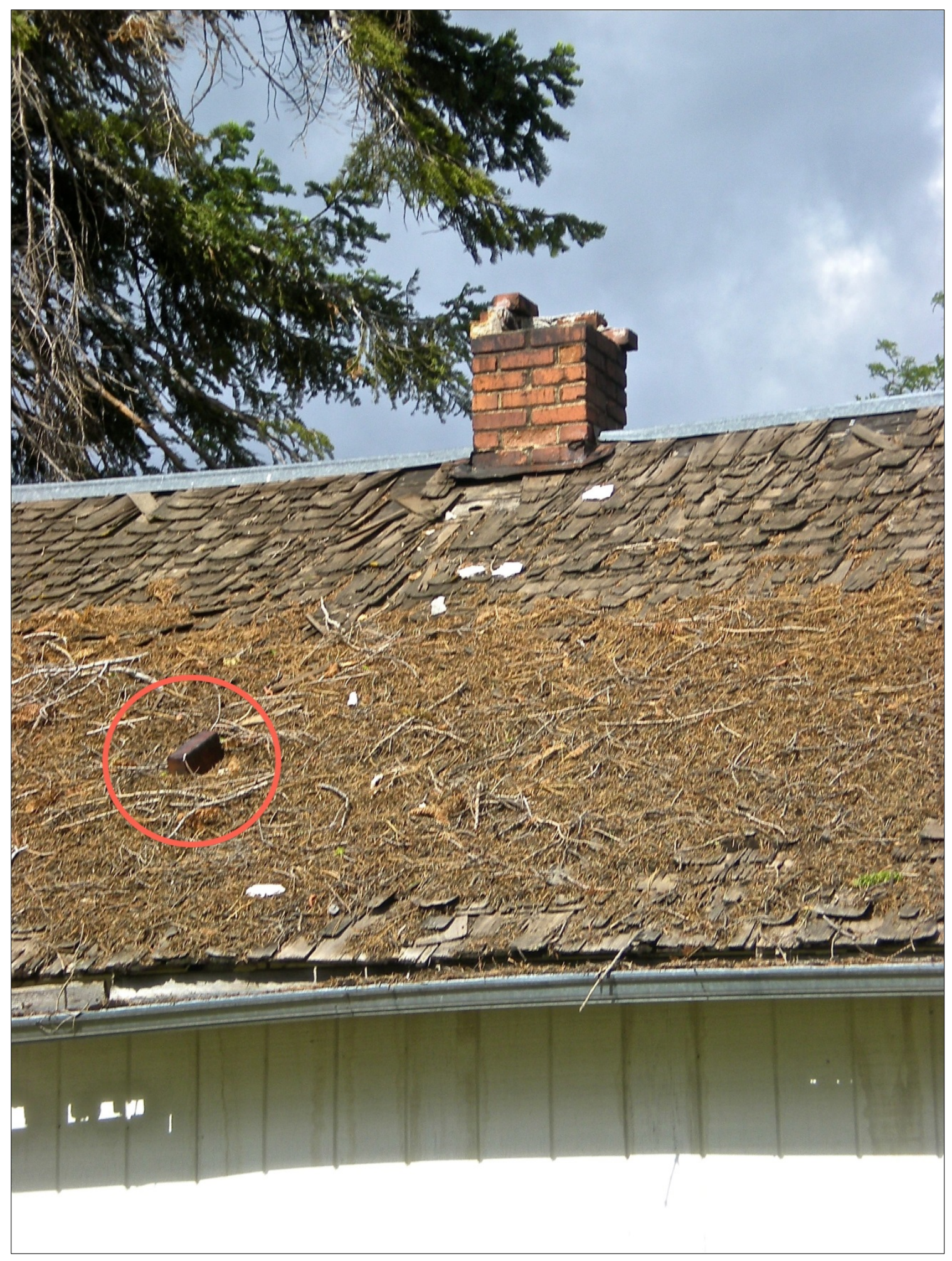

Figure 2-15. Chimney damage to house (site 1.1.35) in Westwood. 


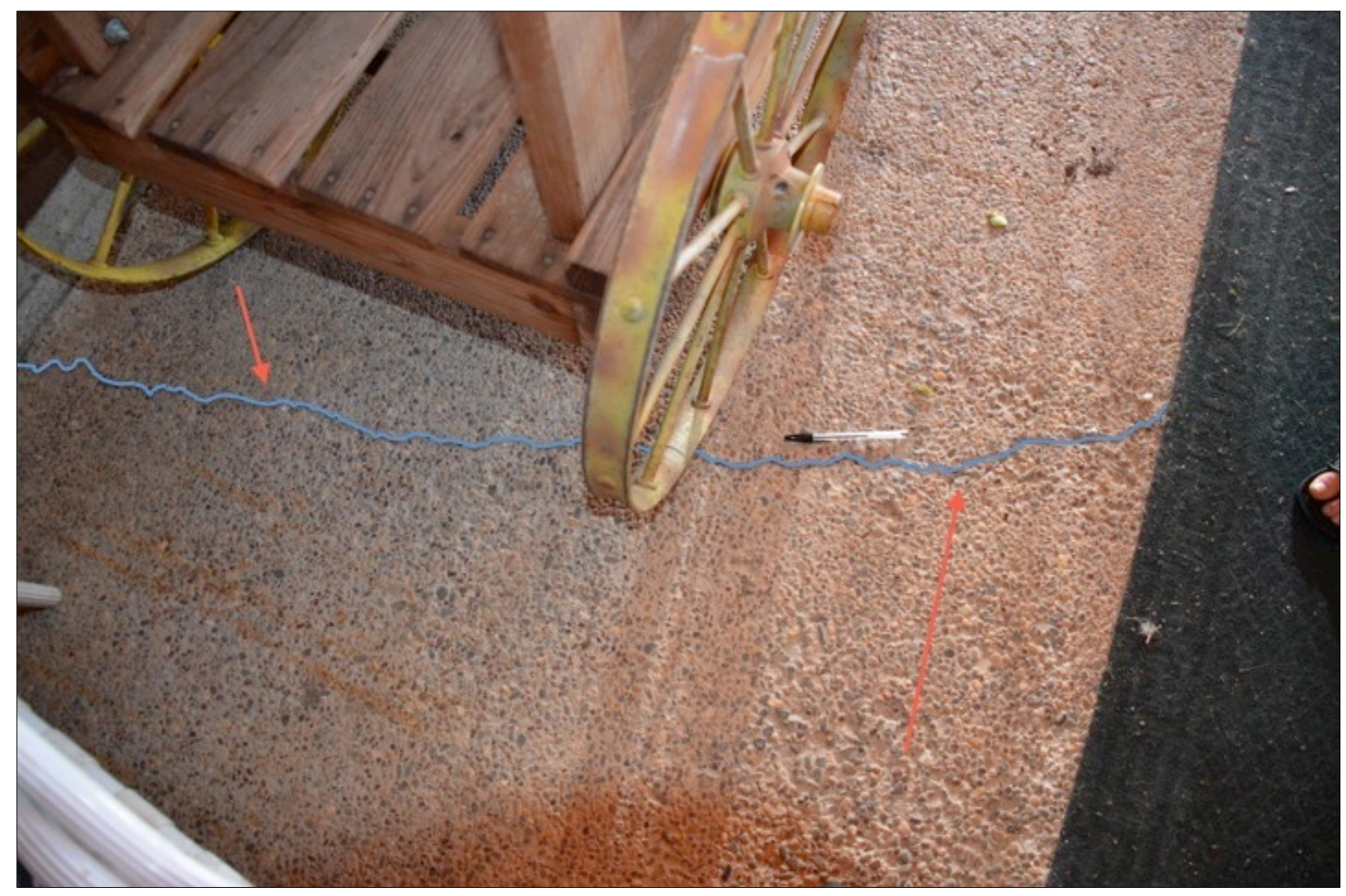

Figure 2-16. Cracked pavement in walkway of site 1.1.41 in LAW. House also suffered cracked foundation, shifted doorframes, cracked sheetrock, and a broken water pipe in the basement. 


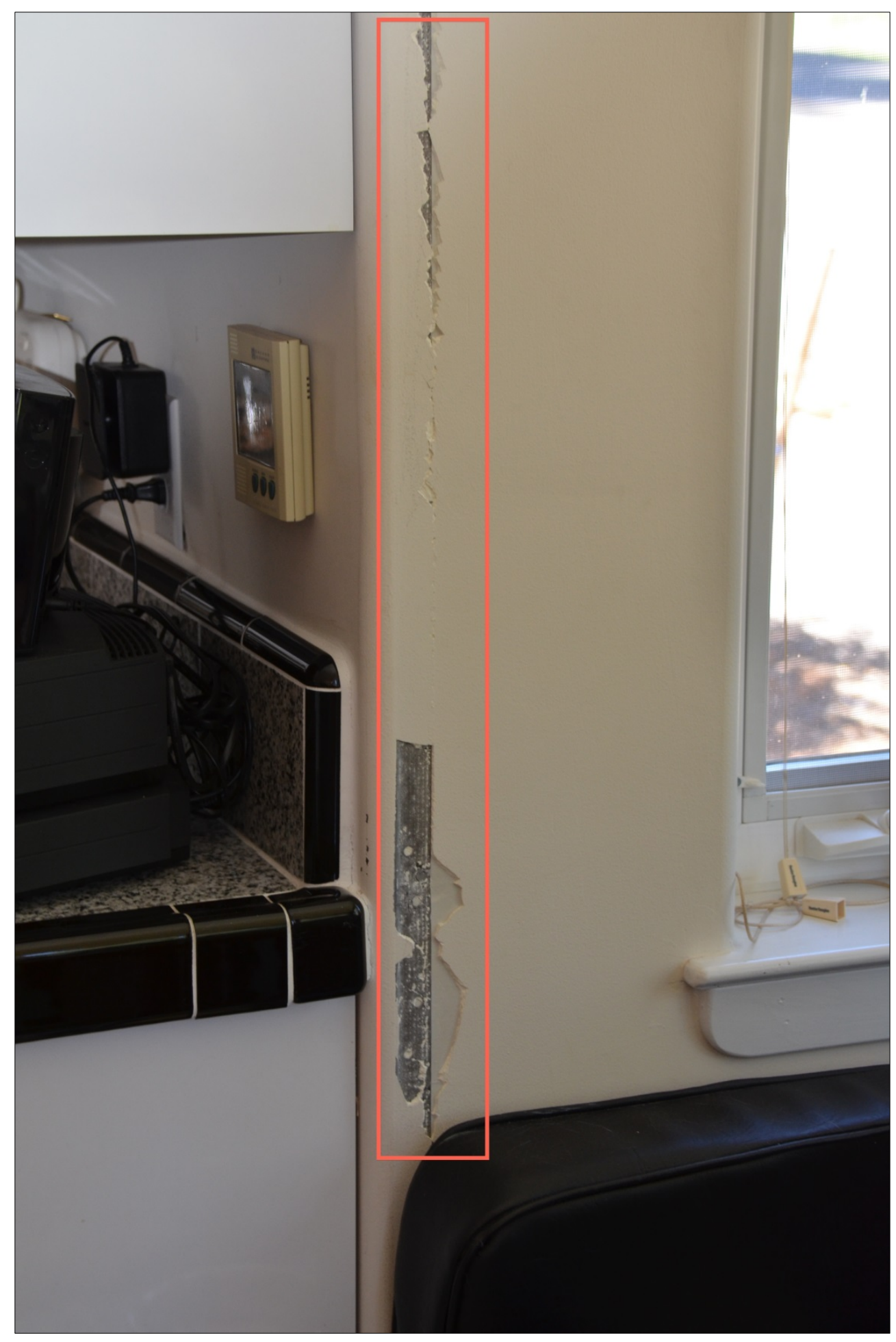

Figure 2-17. Cracked drywall in site 1.1.40 in LAW. Many locations throughout the first story of the house had similar drywall. Drywall in the second story was mostly undamaged. 


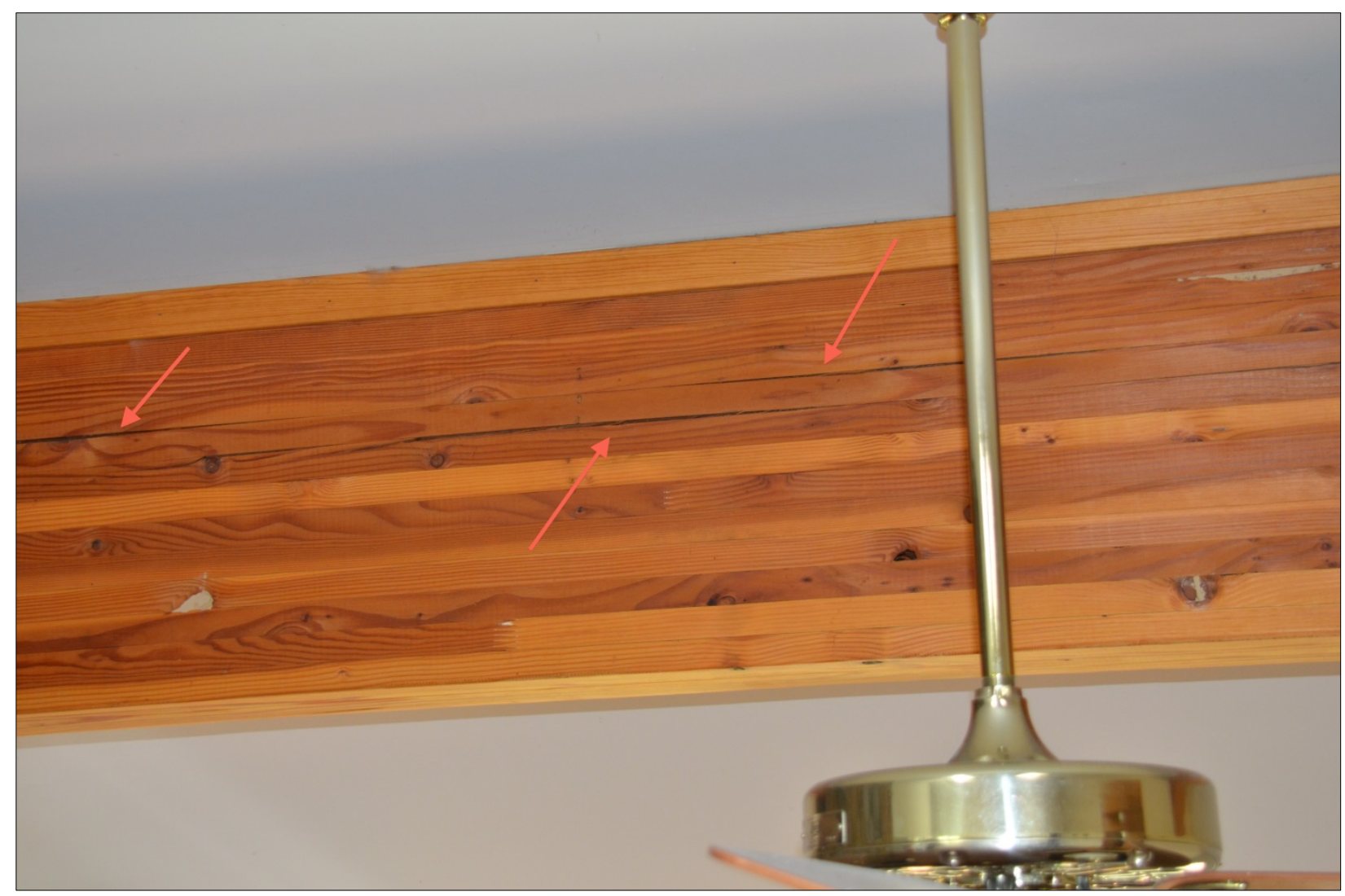

Figure 2-18. Cracks in laminated wooden ceiling beams in site 1.1.40 in LAW. Cracks were present in beams oriented both north-south and east-west. 


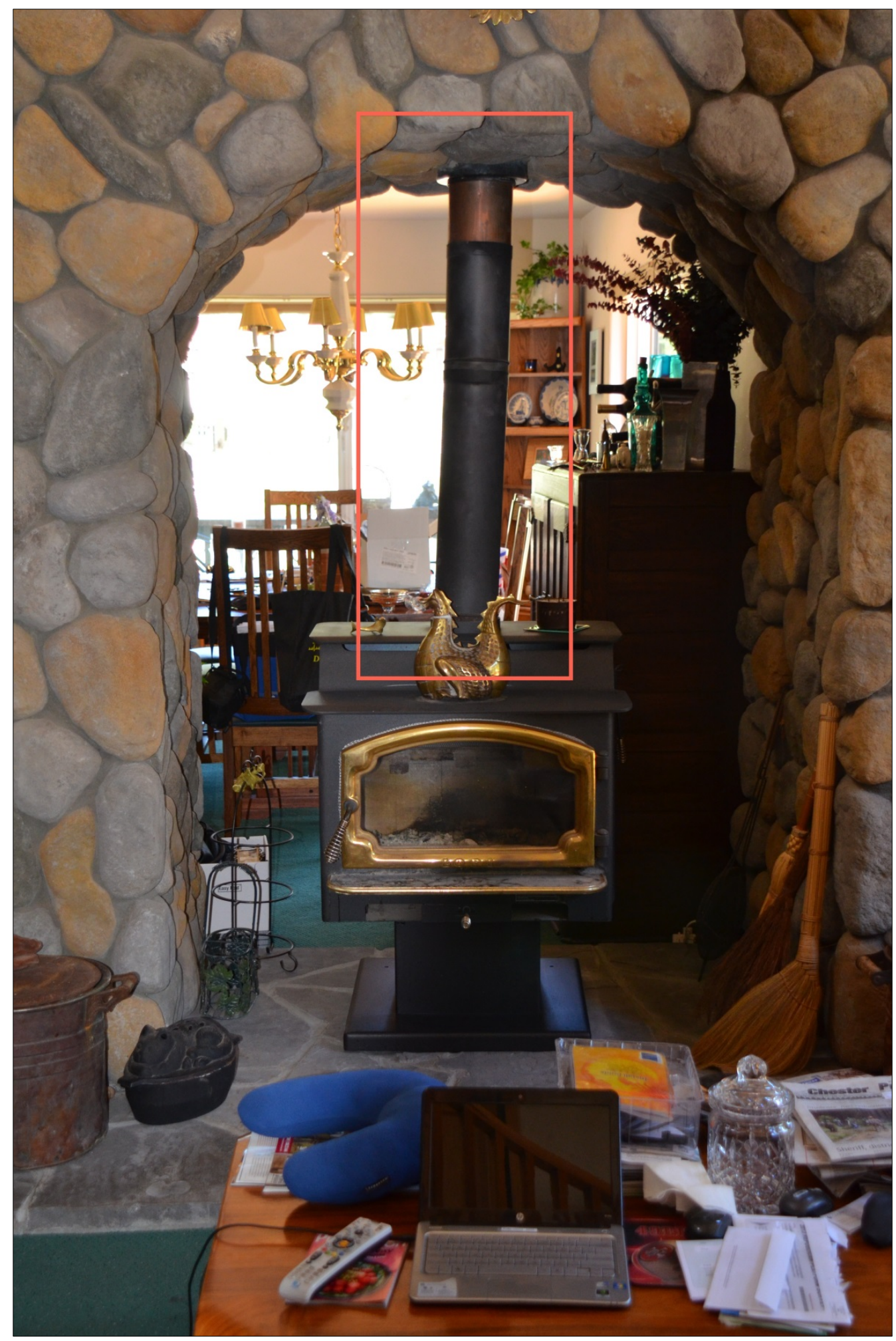

Figure 2-19. Shifted fireplace and chimney flue in site 1.1.40 in LAW. 


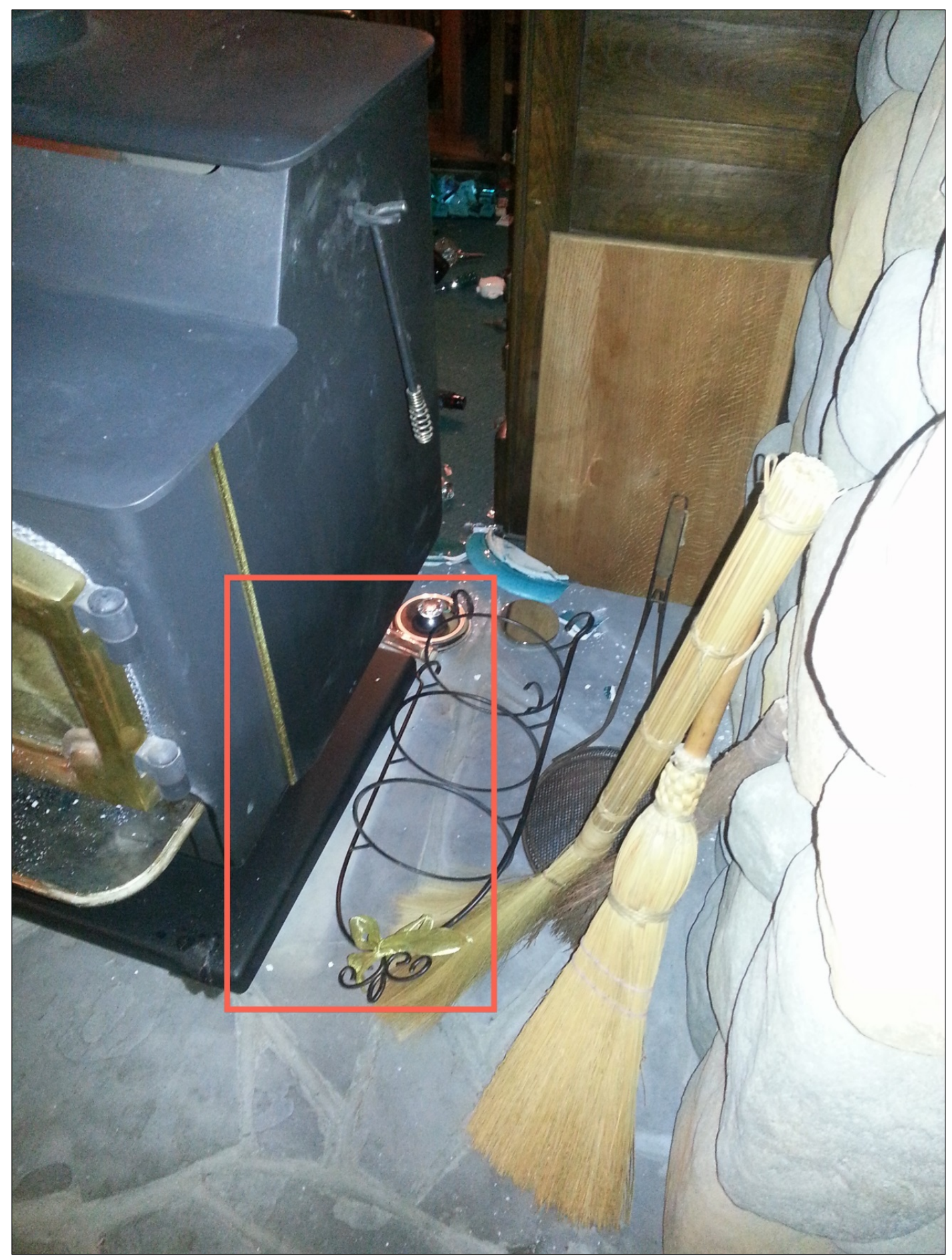

Figure 2-20. Shifted fireplace in site 1.1.41 in LAW. 


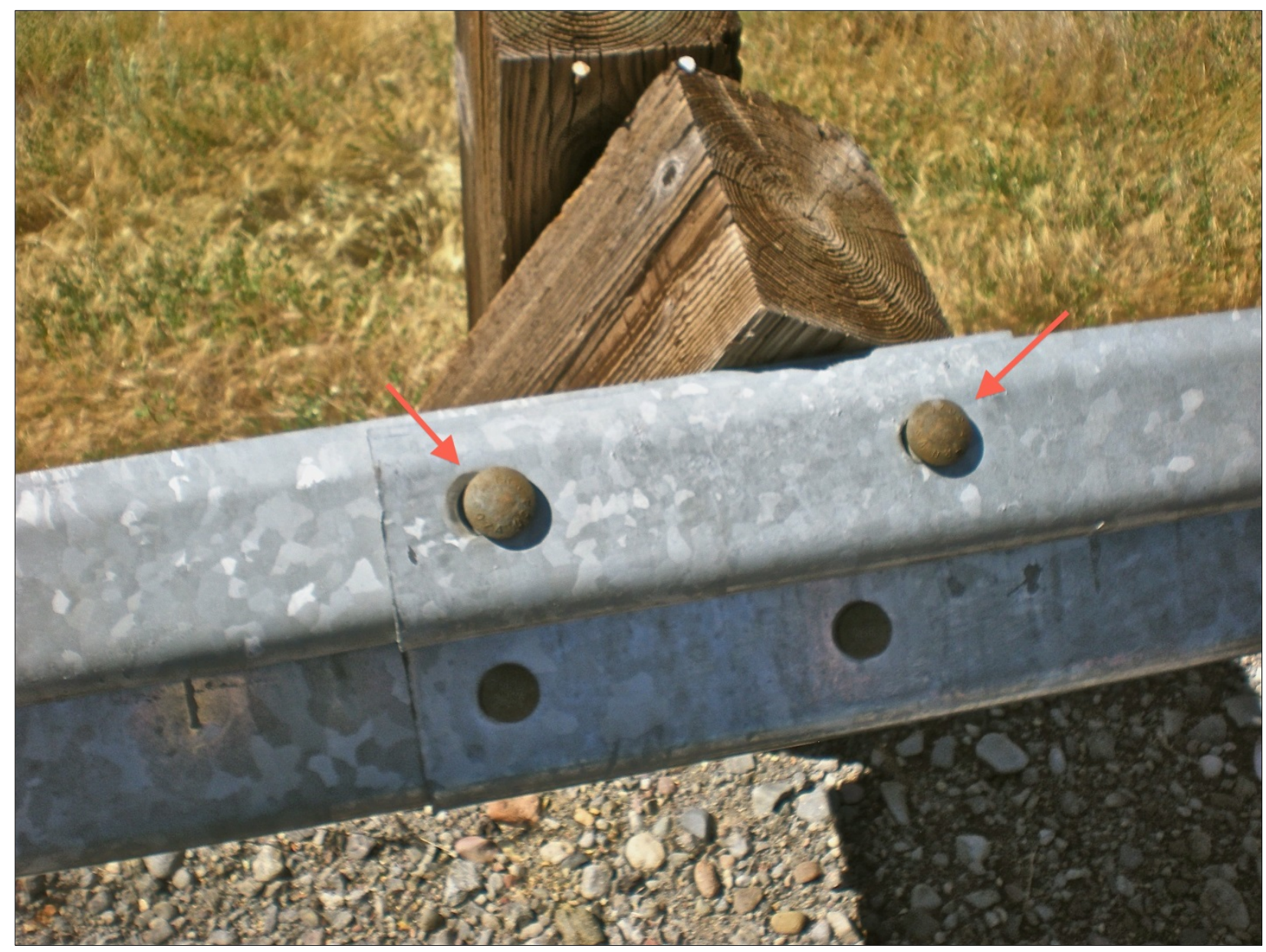

Figure 2-21. Shifted bolts in Butt Valley Dam guardrail, site 1.1.49. Guardrail runs the length of Butt Valley Dam, located at the southern end of Butt Valley Reservoir, approximately $11 \mathrm{~km}$ southwest of the epicenter. The PG\&E accelerometer located on the dam recorded a PGA (peak ground acceleration) of $0.3 \mathrm{~g}$. 


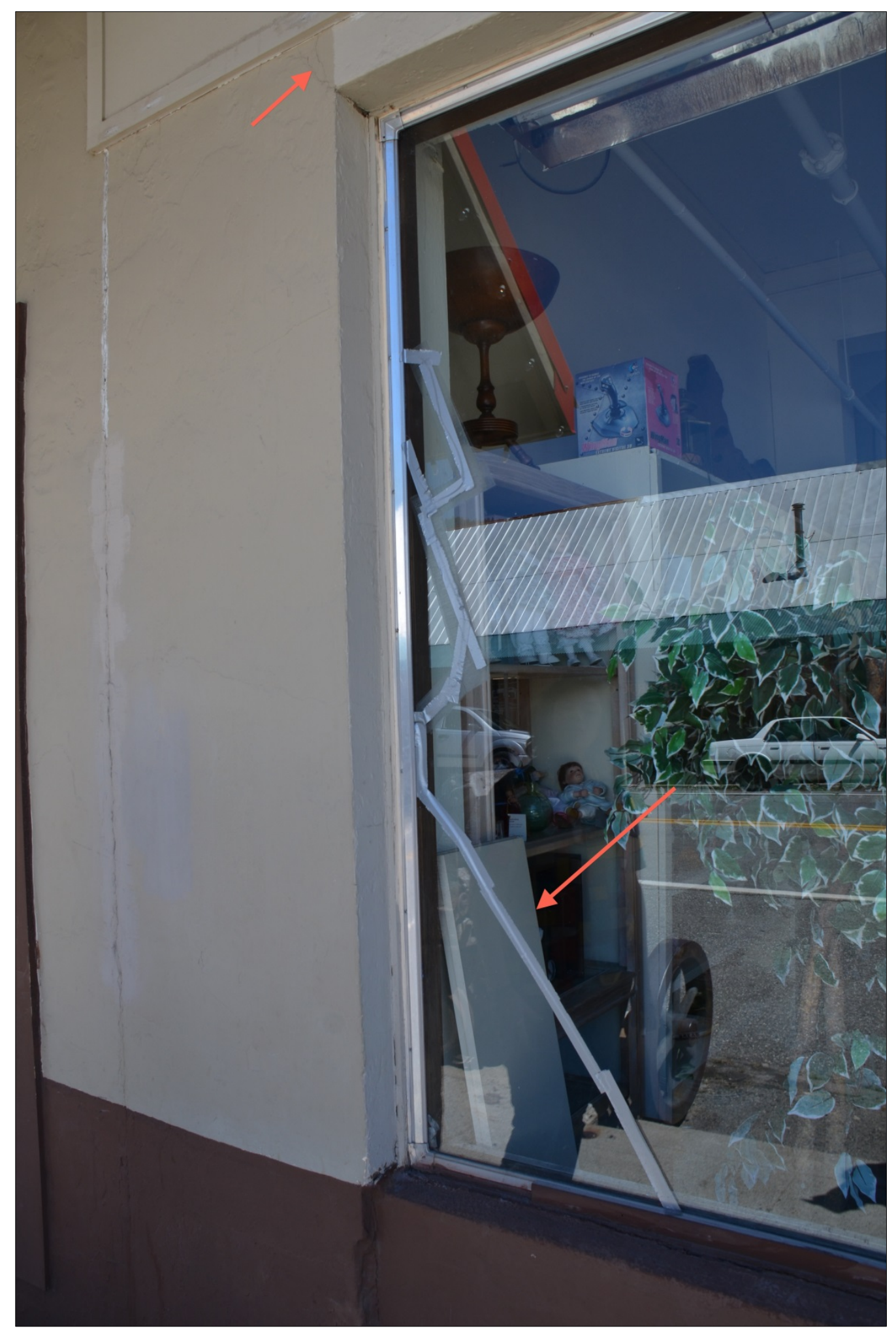

Figure 2-22. C Cracked window in Sierra Lodge, site 1.1.51 in Greenville. 